\title{
Household Savings and Marriage Payments: Evidence from Dowry in India*
}

\author{
S Anukriti $\quad$ Sungoh Kwon ${ }^{\ddagger} \quad$ Nishith Prakash ${ }^{\S}$
}

April 9, 2018

\begin{abstract}
This paper examines how traditional marriage market institutions affect households' financial decisions. We study how bride-to-groom marriage payments, i.e., dowries, influence saving behavior in rural India. Exploiting variation in firstborn gender and heterogeneity in dowry amounts across marriage markets, we find that the prospect of paying higher dowry increases household savings, which are primarily financed through increased paternal labor supply. This is the first paper that highlights this alternative motive for savings in dowry-paying societies. However, we find no impacts of dowry expectations on son-preferring fertility behaviors and investments in girls.
\end{abstract}

JEL Codes: J1, D14, O15

Keywords: Household Savings, Dowry, Marriage Payments, India, Labor Supply, Fertility, Sex Ratio, Child Investments

*We thank Achyuta Adhvaryu, Prashant Bharadwaj, Sonia Bhalotra, Lucas Coffman, Mausumi Das, Anusar Farooqui, Erica Field, Andrew Foster, Delia Furtado, Parikshit Ghosh, Shoshana Grossbard, Rachel Heath, Seema Jayachandran, Rob Jensen, Adriana Kugler, Hyun Lee, Arthur Lewbel, Annemie Maertens, Subha Mani, J.V. Meenakshi, Mushfiq Mobarak, Rohini Pande, Krishna Pendakur, Laura Schechter, John Strauss, Chris Udry, Shing-Yi Wang, David Weil, and seminar and conference participants at the AEA-Econometric Society Joint Meetings, Boston College, Delhi School of Economics, Fordham University, Georgetown University, IFPRI, Indian Statistical Institute, NEUDC, New Frontiers in Development Economics Conference, SEA Meetings, University of British Columbia, University of Connecticut, and University of Southern California for their helpful comments and suggestions.

${ }^{\dagger}$ Department of Economics, Boston College and IZA. anukriti@bc.edu.

$\ddagger$ Department of Economics, University of Connecticut. sungoh.kwon@uconn. edu.

$\S$ Department of Economics and Human Rights Institute, University of Connecticut, IZA, HiCN, and CReAM. nishith.prakash@uconn.edu. 


\section{Introduction}

Household savings are a crucial determinant of welfare, especially in developing countries, where credit and insurance markets are imperfect. However, countries with similar income levels have widely different saving rates. For instance, in 2016, gross national savings as a percentage of GDP was 30 percent in India but only 14 percent in Brazil and 16 percent in Ghana (World Bank data). This paper examines the role of marriage market institutions in explaining the variation in household saving behavior.

We focus on the institution of bride-to-groom marriage payments, i.e., dowry. Marriage payments are widely prevalent in developing countries and often amount to several years of household income (Anderson (2007)). Our geographical setting is rural India where, despite being illegal since 1961, dowry was paid in 95 percent of marriages during 1960-2008 (REDS (2006)). ${ }^{1}$ We study how the prospect of dowry payments at the time of a child's marriage affects parents' current savings, consumption, and labor supply.

Although the relationship between marriage and savings has been previously recognized (Horioka (1987), Tertilt (2005), Wei and Zhang (2011), Du and Wei (2013), Grossbard (2015)), there is no prior work on how the custom of marriage payments affects households' financial decisions. ${ }^{2}$ Thus, we highlight a previously unrecognized motive for savings in dowry-paying societies.

Dowry is typically paid in a lump-sum manner at the time of the wedding. The groom's family often receives further transfers from the bride's family after marriage (Bloch and Rao (2002)) but these tend to be substantially smaller in magnitude. The "lumpy" nature of dowry could be due to the couple's inability to divide marital output during the course of a marriage (Becker (1981)) $)^{3}$ or be driven by the custom of virilocality (Botticini and Siow (2003)). ${ }^{4}$ Faced with a lumpy expense, one way parents of daughters could finance dowries

\footnotetext{
${ }^{1}$ The Dowry Prohibition Act of 1961 prohibits the giving or taking (or the abetting of giving or taking) of dowry in India. The penalty is at least 5 years of imprisonment and a fine no less than INR 15,000 or the value of dowry, whichever is more. The Dowry Prohibition Rules of 1985 made the provisions stricter. More details at http://wcd.nic.in/act/dowry-prohibition-act-1961.

${ }^{2}$ Horioka (1987) describes that future marriage-related expenses are cited as a significant reason for household savings in Japan. Wei and Zhang (2011), Du and Wei (2013), and Horioka and Terada-Hagiwara (2016) find evidence for marriage-related competitive saving motive in China, South Korea, and India, wherein parents' savings respond to the marriage market sex ratios faced by their children.

${ }^{3}$ If the wife's economic contribution to the marital surplus is lower than that of the husband's, it results in a positive dowry at the time of marriage.

${ }^{4}$ In virilocal societies, a daughter leaves her natal home upon marriage to move in with her husband's family. Botticini and Siow (2003) theorize that parents give a large dowry to the daughter
} 
is through borrowing around the time of marriage. However, credit constraints and, most importantly, the illegal nature of dowry prevents formal sector borrowing for the purpose of dowry in India.

An alternative way to raise liquidity for dowry is through savings. Saving for dowry was prevalent even in medieval Florence. In 1425, Cosimo de' Medici established Monte Delle Doti or Dowry Bank, a public fund that sought to assist families in accumulating adequate dowries. The fund accrued a guaranteed interest rate on deposits made upon the birth of a daughter that could be withdrawn after an agreed number of years to become the daughter's dowry (Frick (2011), Strathern (2015), Franklin (2017)). More recently, in 2016, the Turkish government introduced the Dowry Account Savings Plan that encourages young unmarried individuals to save for marriage expenses and guarantees a 10-20 percent state contribution if they save regularly. ${ }^{5}$ It is also widely believed that Indian parents, who are still primarily responsible for arranging and organizing their children's marriages, start saving for dowry as soon as a daughter is born. Yet, there is little prior empirical evidence on the causal impact of the institution of dowry on parents' saving behavior.

We test if parents that face a higher future dowry expense save more. Since dowries are transfers from the bride's family to the groom's family, the dowry expense is higher for parents of a girl relative to parents of a boy. ${ }^{6}$ However, we cannot simply compare household savings after the birth of a girl relative to a boy to estimate the causal impact of future dowry since boy-families and girl-families are likely to differ along other dimensions that are correlated with savings. This is especially true as selective abortion of girls is widespread in contemporary India. ${ }^{7}$

To address this concern, we distinguish between households that differ by firstborn sex. Despite access to prenatal sex-determination technology, the sex ratio at first parity has

upon marriage (and a small bequest) to prevent non-coresident female siblings from free-riding their brothers who work with parents' assets, such as the family farm. The family structure in rural India is still highly virilocal. Daughters almost never live with their parents after marriage, and more than 80 percent of the parents live with their sons who are primarily responsible for working on the family assets. In fact, the equalization of inheritance rights across sons and daughters has only resulted in higher dowries and strategic gifting of family property to sons (Roy (2015)). Thus, lumpy dowries at the time of marriage continue to be the norm.

${ }^{5}$ See https://tinyurl.com/y7jjkxg6 and https://tinyurl.com/y8ag9v67.

${ }^{6}$ Parents of a son may also save for other marriage-related expenses, but, as we show later, the bride's family spends significantly more on the marriage.

${ }^{7}$ For instance, if richer families are more able to afford sex-selective abortions, girls will be born in poorer families, thus biasing our estimate of the effect of future dowry on savings based on a comparison of girl-families and boy-families. Note, however, that poorer households have lower savings; hence the bias would be against finding an impact. 
remained unbiased in India and is frequently used as an exogenous shock in related literature (Das Gupta and Bhat (1997), Visaria (2005), Bhalotra and Cochrane (2010), Anukriti et al. (2016)). We utilize the well-known fact (which we also verify) that Indian parents of a firstborn girl have more girls on average than parents of a firstborn boy (a) due to the presence of son-biased stopping rules $^{8}$ (Clark (2000), Bhalotra and van Soest (2008), Jensen (2012), Rosenblum (2013)) and (b) because the former are more likely to practice sex-selective abortions (Almond and Edlund (2008), Abrevaya (2009), Bhalotra and Cochrane (2010)). So, instead of comparing boy- and girl-families, we compare savings in firstborn-girl (FG) and firstborn-boy (FB) families, as the former face a higher future dowry expense, on average, due to the greater number of daughters. While it is not obvious that total dowry expense should be higher for parents who have more daughters, ${ }^{9}$ in our data, as we show later, increase in the number of daughters significantly increases total dowry paid by parents and does not affect dowry paid per daughter.

To test if differential savings behavior between FG and FB families is due to dowry and not due to other factors, we exploit the variation in expected dowry amounts. We regress household savings on the interaction of firstborn girl dummy and expected dowry, thus testing if savings vary by expected dowry even within FG families. We assume that parents form expectations about dowry amounts by observing dowries paid by brides or received by grooms in their marriage market around the time of birth. We define a child's marriage market by its caste and state (more details in Section 3). For a child born in a given year, we define expected dowry as the average net dowry paid by brides or received by grooms from the same caste and state as the child and who married during the year of the child's birth or the prior four years. We also utilize alternate definitions of expected dowry for robustness checks.

We implement this empirical strategy by using the 2006 round of the Rural Economic and Demographic Survey (REDS) of India. This dataset has numerous advantages over other Indian datasets that have been used in the dowry literature that we discuss further in Section 2. In addition to data on marriage payments, REDS collects rich information on various forms of savings at the household level, such as, savings in financial institutions, in jewelry, in livestock, and in durable goods. This enables us to examine the changes in the entire savings portfolio of a household rather than just one form of saving; our results are

\footnotetext{
${ }^{8} \mathrm{~A}$ son-biased stopping rule means that parents are more likely to stop childbearing after a male relative to a female birth.

${ }^{9}$ For instance, parents who have more daughters may give less dowry per daughter while incurring the same total expense as parents with fewer daughters.
} 
thus less likely to be biased by substitution across different modes of savings.

We find several important results. Our key finding suggests an alternative motive for savings: the prospect of higher future dowry causes increase in current savings. In particular, as expected dowry increases, FG families significantly increase per capita annual savings overall and relative to FB families. The increased savings take the form of formal savings in financial institutions and not savings in jewelry or precious metals that are traditionally considered an integral part of dowry in India. This pattern of saving behavior is consistent with greater access to financial institutions and instruments in rural India and the less liquid nature of jewelry relative to savings in bank accounts during our study period. ${ }^{10}$

The higher savings can be financed in three ways: (1) lower consumption, (2) increased income, and (3) increased debt. We do not observe any change in total, food, and non-food consumption expenditure on items on which data is collected in REDS. However, we find that fathers of firstborn girls work more days in a year relative to FB fathers as expected dowry burden goes up, suggesting that at least part of the increased savings is financed through higher income. There is no significant impact on mothers' labor supply, which is not surprising given the low levels of female labor force participation in India (Afridi et al. (2016), Fletcher et al. (2017)). We find some effect on the likelihood of borrowing, but it is not statistically significant across specifications.

As the severity of income and credit constraints varies by household wealth, we also examine if the results differ for families above and below the poverty line. The effects on savings and father's labor supply are larger and only significant for households that are above the poverty line. This suggests that extremely poor households are too income-constrained to be able to save for their daughters' dowries in advance.

Our second set of results shows that dowry expectations are not a significant explanatory factor for differential fertility and sex-selection by firstborn sex. These findings are critical as they assuage concerns about endogenous fertility decisions, which would introduce bias in the estimated effects on per capita savings. More importantly, they go against the conventional belief that dowry is an underlying cause of son preferring behaviors in India (Miller (1981), Arnold et al. (2002), Das Gupta et al. (2003), Alfano (2015), Bhalotra et al. (2016)), but are consistent with the well-established fact that son preference and its manifestation as sex-selective abortions differ by birth parity and the number of sons.

\footnotetext{
${ }^{10}$ Note that this does not imply that jewelry is no longer a significant part of dowry in India. Our finding simply suggests that parents do not save for dowry through advance savings in jewelry; they may and most likely do utilize the savings in financial institutions to purchase jewelry around the time of marriage.
} 
Finally, we estimate the impact of dowry expectations on human capital investments in children - a relationship on which no previous evidence is available. In dowry-paying societies, household budget constraints imply that bridal families face a trade-off between investing directly in their daughters' human capital or saving for a dowry to attract a desirable sonin-law (Anderson (2014)). In addition, for a given expected dowry amount, parents of a daughter who foresee higher returns to female education (or health) on the marriage and labor markets, may increase savings by a lesser amount and may instead invest more in the daughter's human capital, relative to parents who foresee lower returns to female human capital investments. We are not aware of any paper that attempts to test these theoretical predictions as proposed by Anderson (2014). Using a variety of outcomes as proxies for health investments in children, we do not find any evidence that dowry expectations impact children's health overall or the gender gaps in them. Similarly, there is no effect on girls' years of schooling. However, we do find some evidence that years of education decrease with expected dowry for sons in FG families relative to FB families, potentially due to an increase in the likelihood of work (like FG fathers) to finance the increased savings.

Our results emphasize the crucial role of traditional cultural institutions in determining economic behavior. We make a substantial contribution to the literature on marriage payments, especially that on dowry. The bulk of previous work on dowries has been theoretical (e.g., Botticini and Siow (2003), Anderson (2007), Anderson and Bidner (2015)). Empirical research on dowry has been largely limited to marriage market explanations for dowry trends (e.g., Rao (1993), Edlund (2006), Anderson (2007)). ${ }^{11}$ In comparison, the literature on the effects of dowry has been miniscule. While Alfano (2015) and Bhalotra et al. (2016) seek to study how dowry impacts fertility and sex-selection, they do not directly estimate the effect of dowry on their outcomes, unlike our paper. ${ }^{12}$ Deolalikar and Rose (1998) and Rose (2000) have examined the association between female birth, savings, and parents' time allocation in India, but they do not show that dowry is the underlying mechanism for their findings. Moreover, their analysis is based on an older, unrepresentative, and small dataset of 240 households from six villages in three districts of rural South Central India. Ashraf et al. (2016) examine the effects of marriage payments on female education, but in the context of bride price. Corno et al. (2017) compare dowry-paying and bride-price paying societies and find that the direction of marriage payments matters for the effect of economic shocks on

\footnotetext{
${ }^{11}$ Logan and Arunachalam (2014) provide a detailed and comprehensive discussion of the dowry inflation debate. Ambrus et al. (2010) examine the emergence of dowry in Bangladesh.

${ }^{12}$ Alfano (2015) exploits a nationwide, one-time change in the dowry legislation, while Bhalotra et al. (2016) utilize a one-time shock in global gold price.
} 
age at marriage in a society. However, we are unaware of any study that estimates the causal impact of dowry on household savings, parental labor supply, and investments in children.

Our identification strategy makes a methodological contribution by providing a novel source of within-country variation in dowry costs faced by households, that can be used to further examine the consequences of dowry. The lack of a credible source of variation in dowry has been a key constraint in the literature so far. We believe that our approach has broader relevance than the variation in global gold price or a one-time change in the national dowry law that have been used in previous work.

Our findings are also relevant to the literature on barriers to savings in low-income countries. This literature suggests that the low levels of saving among the poor may be due to behavioral factors such as imperfect self-control and information and knowledge gaps, among other things (see DellaVigna (2009) and Karlan et al. (2014) for an overview). The seemingly greater ability of parents to overcome savings constraints in the context of dowry as implied by our results, could be due to a better understanding of the costs and returns relative to other saving motives. The social and economic costs that accrue from the inability of parents to get a daughter married to an appropriate groom by a certain age due to the lack of sufficient dowry tend to be quite high (Bloch and Rao (2002), Sekhri and Storeygard (2014), Maertens (2013)). Moreover, parents have relatively good information on the prevailing rate of dowry in the relevant marriage market and there is typically no uncertainty about whether or not they will need to pay dowry. Mental accounting for dowry-related saving may also be easier than for other financial decisions. Further, intra-household disagreement on saving for dowry is likely to be low. Given that marriage is a frequent and elaborate public event in rural India, each wedding in one's social circle is likely to serve as a "reminder" to save for dowry thereby overcoming the limited attention bias that could lead to under-saving in other circumstances. Peer influence is also likely to be stronger around cultural institutions such as dowry.

Finally, we make a modest contribution to the large literature on income and consumption smoothing (Morduch (1995)). Our finding that households use savings and adjust labor supply to smooth the negative income shock due to dowry is consistent with classical life-cycle and permanent income models (Franco and Brumberg (1954), Friedman (1957), Campbell (1987), Jappelli and Pistaferri (2010)). 


\section{Data and Background}

Our primary analysis uses the most recent 2006 round of REDS; ${ }^{13}$ REDS is a nationally representative survey of rural Indian households first carried out in 1968. Uniquely among household surveys, REDS collects detailed information on savings and marriage payments, along with labor supply and other economic and demographic variables. In addition, we use data on fertility, sex-selection, and child investments from the rural sample of 1992-93, 1998-99, and 2005-06 rounds of the Demographic Health Survey of India, also known as the National Family Health Survey (NFHS).

\section{$2.1 \quad$ Expected Dowry}

Unlike other datasets, such as the India Human Development Survey (IHDS), that record total marriage expenditure in the year of survey by families similar to the respondent's family, 2006 REDS collected data on actual payments by brides and grooms in the surveyed households. ${ }^{14}$ Specifically, it reports the value of gifts received or given at the time of marriage in addition to the year of marriage and demographic information of spouses (e.g., caste and years of schooling) for 17,401 marriages that took place during 1986-2007. ${ }^{15}$ We compute net dowry as the difference between "gross payments by the bride's family to the groom or his family" and "gross payments by the groom's family to the bride's family" and deflate the nominal amounts using the 2005 national Consumer Price Index. Figure 1 describes the variation in the dowry variable; the top panel shows the raw data on the real net dowry paid by the bride's family, by year of marriage; and the bottom panel displays separately the real

\footnotetext{
${ }^{13}$ Note that, although the first set of interviews in the 2006 REDS were conducted in 2006, 84 percent of the interviews took place in 2008.

${ }^{14}$ In addition to the IHDS, other researchers have used dowry data from the International Crops Research Institute for the Semi-Arid Tropics (ICRISAT) and the Status of Women and Fertility (SWAF) surveys. While the ICRISAT data contains retrospective information on marriages, it is only a small survey of 240 households from six villages in three districts of rural South Central India collected in 1983. Although the SWAF survey is relatively new and was conducted in 1993-94, a key shortcoming of it is that it does not report specific dowry amounts and instead provides five ordinal categories that nominal dowries fall into.

${ }^{15}$ The surveys were administered to household heads who provided information on marriages of other household members. Male heads were asked about their non co-resident children, siblings, and non co-resident parents, while female heads were asked about their non co-resident children, and the siblings and non co-resident parents of their husband. One omission that 2006 REDS made is to not collect data on dowries received by co-resident sons of the head. However, since a co-resident son would be married to another head's non-co-resident daughter (typically from the same state and caste given the structure of the Indian marriage market), the dowry information for co-resident sons' marriages may still be in our data.
} 
value of gifts from the bride's family and from the groom's family, by year of marriage. ${ }^{16}$

We plot the distribution of net and gross marriage payments in Figure 2. ${ }^{17}$ The proportion of marriages with a negative net dowry, i.e., where the groom's family paid more to the bride's family than the other way around, is non-zero, but quite small. The vast majority of the marriages involved positive net dowry payments to the groom's family. We do not observe any marriages where the value of gifts was reported to be zero. ${ }^{18}$

Ideally, to examine how dowry expectations impact household saving behavior, we would like self-reported data on how much dowry a family expects to give or receive when their child gets married. Unfortunately, we are unaware of any dataset that has this information. Consequently, we construct a proxy for the true expectations - our expected dowry variableby assuming that households use the information on actual dowries to form expectations. We assume that, after a child is born, parents form expectations about the dowry they will pay or receive in the future by observing marriages that have recently taken place in their reference group or the marriage market. Specifically, we define expected dowry as the average net dowry paid by brides or received by grooms from the same caste and state as the child and who married during the year of the child's birth or the prior four years. ${ }^{19}$

The accuracy of the expected dowry variable depends on how correctly we define marriage markets and capture the process of dowry expectation formation. We assume that the relevant marriage markets are based on caste (and religion) and state. This is a reasonable assumption given the highly endogamous nature of the Indian marriage market. In the 2005 IHDS, only 4.4 percent of women were married to a spouse from a different caste. ${ }^{20}$ In fact, genetic evidence suggests that the practice of endogamy in India is several thousand years old (Moorjani P. (2013)). In addition to this "horizontal" preference for same-caste marriages, inter-subcaste $($ jati) marriages are governed by strict rules of hierarchy. Although caste is primarily a Hindu phenomenon, the notion of caste-based hierarchy remains well-preserved

\footnotetext{
${ }^{16}$ We also report the composition of dowries, i.e., the kind of things that are usually given as gifts at the time of a daughter's marriage, in rural India using the 2004-05 IHDS in Table A.3. This information is not recorded in the REDS data.

${ }^{17}$ See Chiplunkar and Weaver (2017) for documentation of the prevalence and evolution of dowry in India using the 1999 round of REDS.

${ }^{18}$ However, our data does contain marriages with missing information on gifts. A detailed discussion of this issue and how we deal with it is in Appendix B.

${ }^{19}$ We trim off the top 1 percent of the dowry payments before constructing the expected dowry variable.

${ }^{20}$ Using responses to matrimonial advertisements in a Bengali newspaper, Banerjee et al. (2013) find evidence in favor of a strong preference for in-caste marriage - e.g., the bride's family is willing to trade-off the difference between no education and a master's degree in the prospective husband to avoid marrying outside their caste. Also see Borker et al. (2017).
} 
among many other religious groups in India. ${ }^{21}$ Inter-religious marriages are even less common than inter-caste marriages. While patrilocal exogamy is widely practiced, most people marry within their state. To illustrate, less than 4 percent of the population had moved across states in the last ten years according to the 2001 Census data. ${ }^{22}$

We also assume that parents form expectations about future dowries based on recent dowries within their caste and state of residence at the time of the child's birth. We also use two alternate definitions of dowry by changing the years over which the average is calculated and by using both caste and religion to define the marriage market to modify how expectations are formed. Our expected dowry variable is a significant predictor of the actual dowry paid at the time of marriage. ${ }^{23}$ Figure 3 shows the scatter plot overlaid with the linear prediction plot. Our definition of expected dowry essentially assumes that parents have static or adaptive expectations, i.e., they expect the value of dowry next period to be equal to the weighted average of dowry in the past few periods. If dowry follows a random walk, then the static expectation is also the rational expectation. We explicitly test if the dowry data follows a random walk by performing the modified Dickey-Fuller $t$ test for a unit root in which the series has been transformed by a generalized least-squares regression. The results (in Appendix Table A.1) show that the null hypothesis of a unit root or random walk is not rejected for all lags in the model.

Variation in the expected dowry variable: In our sample, we have 4 caste groups (upper castes, SCs, Scheduled tribes (STs), and Other Backward Classes (OBCs), 17 states, and 22 years, yielding 1,285 caste-state-year groupings. ${ }^{24}$ Thus, the variation in our key explanatory variable, expected dowry, is at a more aggregate level (caste-state-year) than our savings data, which is at the household level. Figure 4 shows the variation in our expected dowry variable by year of birth of the firstborn child and Figure 5 shows the same by caste groups. ${ }^{25}$

Recall bias in dowry data: Like most survey data, one may be concerned about the recall bias in the reported dowry variable, especially when the year of marriage is too far back

\footnotetext{
${ }^{21}$ For instance, in the 2009 National Sample Survey, 31 percent of Sikh households identified themselves as belonging to a Scheduled Caste (SC).

${ }^{22}$ Similarly, among individuals aged 25 years or older surveyed in the 2008 National Sample Survey, 89 percent of women and 93 percent of men lived in the same state where they were born.

${ }^{23}$ Using data on individuals whose year of birth and year of marriage fall within our data, we ran an OLS regression of the actual dowry paid at the time of marriage on the expected dowry (using our definition) in the year of birth. The coefficient of expected dowry is 0.490 with a p-value of 0.000 .

${ }^{24}$ Due to missing data, the bulk of which is for ST, we do not have all 1,496 cells.

${ }^{25}$ Although REDS reports a household's jati (sub-caste), the number of jati-state-year cells is not large enough to carry out the empirical analysis by defining the expected dowry by sub-caste.
} 
in time. To examine the extent of the recall error, we utilize data from the 1999 round of REDS and compare average dowry paid by year of marriage for years that are available in both rounds. Appendix Figure A.2 shows that, for the sample period of our savings analysis (1986-2007), the two rounds report similar dowry amounts. Thus, recall bias is unlikely to be a significant issue for our regression estimates. Given the salience of marriage and dowry in the Indian context, it is unsurprising that the recall error is not substantial.

External validity of dowry data: We corroborate the cross-sectional patterns by caste and religion in 2006 REDS using dowry data from 2005 IHDS. Unlike REDS, IHDS elicits dowry data indirectly by asking respondents how much money is usually spent at the time of the marriage by a groom's or a bride's family that is similar to the respondent's family; this information is only collected for the survey year. Table A.2 shows the sample means of the net dowry paid by the bride's family calculated using these responses for various caste and religious groups. Although our paper focuses on rural India because REDS does not cover urban areas, we also report urban dowries from the IHDS for comparison. Reassuringly, the patterns in Table A.2 are identical to those in the REDS data in 2004-05. ${ }^{26}$ The similarities between REDS and IHDS also assuage concerns about differential under- or over-reporting of dowry payments and receipts by the sampled households.

\subsection{Savings}

Our primary outcomes of interest are different measures of saving. Using the detailed information available in REDS, we construct the following measures of household-level saving: total savings, savings in financial institutions, ${ }^{27}$ savings in jewelry, savings in livestock, market investments, ${ }^{28}$ and savings in durable goods. The flow saving variables are constructed based on the value of each item purchased (deposits) and sold (withdrawals) during the year before the survey. For the bulk of the paper, we only utilize cross-sectional information on savings from the 2006 REDS. $^{29}$

The literature describing saving behavior of households in developing countries is quite limited, primarily due to the lack of micro-level data. The bulk of the existing research examines micro-savings for small samples that are not nationally representative (typically,

\footnotetext{
${ }^{26}$ Among various questions related to spending at the time of marriage, 2005 IHDS also reports 'average cash' given as a gift at the time of the daughter's marriage. The average cash reported is equal to INR $18,209(\$ 289)$.

${ }^{27}$ Saving in financial institutions comprise savings in commercial banks, private banks, post office, chit funds, self-help groups, and co-operative societies or banks.

${ }^{28}$ These comprise investments in the stock market, mutual funds, and life insurance.

${ }^{29}$ Later, for robustness check, we attempt to combine data the 2006 REDS with data from the 1999 REDS to create a savings panel.
} 
in the context of randomized control trials) or is based on incomplete data on the various forms of savings (see Karlan et al. (2014) for a literature review). For India, we are not aware of any other nationally representative survey that collects detailed data on various forms of savings, except REDS. ${ }^{30}$ Information on various types of savings allows us to examine the changes in the entire savings portfolio of a household rather than just one form of saving; we can thus capture substitution across different modes of savings.

Table 1 shows that savings in financial institutions is the biggest component of the annual flow of household savings. This is true even for the annual stock of savings; however, unlike the flow measure, the magnitude of the stock of jewelry, livestock, and other durable goods is comparable to the stock of savings in financial institutions. This pattern of larger stock but smaller flow of durable goods savings is consistent with the fact that purchases of durable goods tend to be less frequent relative to cash savings. In this paper, we primarily focus on the annual flow of savings; however, later we also briefly discuss the effects on the stock of savings. Average per capita household (flow) savings in financial institutions, cash savings, and interest earned was INR 647 (or $\$ 10$ ). The average per capita flow of savings across all categories in our data was INR 1132 (or \$17) or 19 percent of the per capita household expenditure in 2007 (reported in 2008). Figure 6 plots the distribution of per capita household savings in financial institutions, cash savings, and interest earned. Figure 7 displays how average per capita savings in financial institutions vary across states and caste groupssavings decrease as one moves down the caste hierarchy and there is substantial cross-state heterogeneity in saving amounts. Among upper castes, the states of Gujarat, Kerala, and Punjab have the highest saving rates; as we will see later, these states also rank high in terms of average dowries.

\subsection{Other variables}

Our secondary outcomes of interest are parents' days worked, fertility, and the sex ratio of children. The employment history in 2006 REDS provides the number of days worked each year between 1986 and the year of survey, which we use to construct a panel data set of parents' labor supply.

We provide summary statistics that describe the socioeconomic characteristics of our sample in Table 2. An average household expects to pay or receive INR 26,120 as dowry. ${ }^{31}$

\footnotetext{
${ }^{30}$ The Debts and Investment Schedule of the National Sample Survey of India collects household data on assets and liabilities but does not include a roster of household members, which is essential for our empirical strategy.

${ }^{31}$ The INR 26,120 (or \$412) amount is roughly similar to the dowries reported in Figure 1 of Logan and Arunachalam (2014) during 1923-78 and the average net real dowry per marriage in
} 
Educational attainment is low - the years of schooling for an average father and mother are, respectively, seven and four. OBCs are the largest caste group in the sample (45 percent), followed by other upper castes (29 percent), SCs (17 percent), and STs (9 percent). In terms of religion, Hindus are the majority (89 percent), followed by Muslims (6 percent), and Sikhs (4 percent). Finally, approximately 43 percent of our sample is below the poverty line (BPL).

\subsection{Sample-selection criteria}

First, we restrict our sample to households where all children have the same mother, thus dropping 17.74 percent of the sample. We do this for several reasons. When households have more than one mother, there is more than one firstborn. As savings data in REDS is available only at the household level, it is difficult to match parents' savings with firstborn sex in families that have more than one mother. Moreover, REDS does not report the birth order of children; so we have to deduce it from child age. In households with more than one mother, data constraints make it difficult to match children with their mother, making it impossible to deduce birth order. Second, we restrict the sample to those families where the mother reports that her first child is alive. Then we use the information on the motherreported age of the oldest living child to assign firstborn status. If firstborn girls are more likely to die than firstborn boys in lower socioeconomic status families, this restriction biases us against finding an effect on savings. Third, we restrict the sample to households where the firstborn child is unmarried and co-resides with the parents to examine how savings are affected before the child gets married. Lastly, we drop from our sample the small number of households that were surveyed in 2006 and 2007, as the bulk of the 2006 REDS interviews were conducted in 2008 .

\section{Empirical Strategy}

Our goal is to estimate the causal effect of expected future dowry payments on parents' current saving behavior. We utilize the fact that dowry affects parents of boys and girls in the opposite manner - the former expect to receive and the latter expect to pay dowry upon marriage - so the savings response should differ by the gender of the child. However, we cannot simply compare household savings in families after a female versus a male birth since boy-families and girl-families are likely to differ along other dimensions that are correlated with savings. If girls are born in relatively larger families as compared to boys due to son-biased stopping rules (Clark (2000), Bhalotra and van Soest (2008), Jensen (2012), Rosenblum (2013)), then girl-families would mechanically have lower savings per capita,

2007 was equivalent to 14 percent of annual household income. 
irrespective of dowry expectations. Similarly, if sex-selective abortions are more prevalent among groups with certain socioeconomic characteristics that are also correlated with savings, our estimates are likely to suffer from the omitted variables bias. For instance, if richer households are more likely to have sex-selective abortions, girls are more likely to be born in poorer households that likely have lower per capita savings, thereby introducing bias in our estimates. To address these concerns, we instead distinguish between households that differ by firstborn sex.

Exogeneity of firstborn sex. Despite access to sex-selection, the sex ratio at first parity has remained unbiased in India and is frequently used as an exogenous shock in related literature (Bhalotra and Cochrane (2010), Rosenblum (2013), Anukriti et al. (2016), Milazzo (2017), Kugler and Kumar (2017)). Figure 8 shows that there has been no change in the proportion of females among first births in India over time, despite changes in the availability of prenatal sex-selection technology. Moreover, we do not find significant differences between FB and FG families in terms of socioeconomic characteristics such as expected dowry, caste, religion, father's years of schooling, except for small differences in mother's schooling and being SC (Table 2). A formal test of orthogonality, where we regress expected dowry on FG dummy and several other controls, yields an insignificant and extremely small coefficient on the $\mathrm{FG}$ indicator ( $\mathrm{p}$-value $=0.39)$.

FG families have more girls. Moreover, Indian parents are more likely to practice sex-selective abortions after a firstborn girl (Almond and Edlund (2008), Abrevaya (2009), Bhalotra and Cochrane (2010), Anukriti et al. (2016)) and follow son-biased stopping rules, resulting in more girls on average in FG relative to FB households. In our data, the average number of girls in FG families is 1.694 as compared to 0.613 girls in FB families. The opposite is true for the average number of boys which is lower in FG families $(=0.906)$ than in FB families (=1.671).

Dowry expense is higher in FG families. This suggests that FG families may face higher total anticipated dowry expense that FB families. This may not be the case, however, if parents with more daughters pay sufficiently lower dowry per daughter than families with fewer daughters, or if FG families compensate by having more sons that bring dowry. Our data allows us to test this. Table 3 shows that the total dowry paid (across all daughters) is higher when a household has more married daughters, but there is no significant effect of the number of daughters on dowry paid per daughter. This is reasonable as a substantially lower dowry offer comes with the risk of not being able to find a suitable groom for the daughter - a highly undesirable outcome for Indian parents. Moreover, as the net number of daughters - defined as the difference between the number of daughters and the number of sons-increases, there is a significant increase in the difference between dowries paid for 
daughters and dowries received for sons. Thus, firstborn gender can be considered a quasirandom dowry shock to the household.

However, simply comparing FG and FB families is also not sufficient. Differential returns from (or costs of) a son versus a daughter may be due to factors other than dowry, such as higher male productivity in agriculture. Parents of a daughter may also save more relative to parents of a son to support themselves during old age, as the custom of patrilocality implies that daughters (and not sons) move out of the natal home upon marriage. To explicitly take into account the contribution of dowry expectations on savings, we, therefore, interact the firstborn girl dummy with the expected dowry variable. This allows us to control for the main effect of FG, that will capture all other non-dowry related reasons due to which saving and other behaviors may differ by firstborn sex. Moreover, the interaction specification allows us to flexibly control for other omitted variables that may be correlated with expected dowry and our outcomes. Next, we describe the precise specifications that we employ.

\subsection{Savings}

To investigate whether FG parents save more than FB parents due to expected future dowry payments, we estimate the following specification:

$$
\begin{aligned}
\text { Saving }_{i c s t}^{2008} & =\alpha+\beta_{1} \text { FirstGirl }_{i} \times \text { Dowry }_{c s t}+\beta_{2} \text { Dowry }_{c s t}+\beta_{3} \text { FirstGirl }_{i} \\
& +\pi_{s t}+\phi_{c t}+\psi_{s c}+\eta_{c} \text { FirstGirl }_{i}+\eta_{s} \text { FirstGirl }_{i}+\eta_{t} \text { FirstGirl }_{i} \\
& +\omega_{c}+\delta_{s}+\theta_{t}+\mathbf{X}_{i}^{\prime} \gamma+\epsilon_{i c s t}
\end{aligned}
$$

where Saving 2008 denotes various flow measures of per capita household saving last year reported in 2008 by household $i$ from caste $c$ in state $s$ and whose first child was born in year $t$; FirstGirl $i$ indicates that the firstborn child in household $i$ is female; Dowrycst is expected dowry defined as the average dowry paid by brides from caste $c$ in state $s^{32}$ who were married during the year of the child's birth or the prior four years (i.e., during $t, t-1, t-2, t-3, t-4) ;{ }^{33} \mathbf{X}_{i}$ is a vector of covariates comprising parents' years of schooling and indicators for religion and the month of survey. We report unweighted regressions in the main set of tables. However, our results remain the same when we use weights. ${ }^{34}$ Standard

\footnotetext{
${ }^{32}$ State reflects the state of residence at the time of survey, and not necessarily the state of marriage or the state of first birth. However, this is unlikely to be a major source of measurement error due to low inter-state migration in India, especially after marriage.

${ }^{33}$ The robustness checks using alternate definition of dowry expectation are provided in Section 5.

${ }^{34}$ The 2006 REDS data does not provide sampling weights; hence we construct them in the following manner, based on Andrew Foster's suggestion. Using the village listing data which includes all households in REDS villages, we create an indicator for the households that are actually sampled
} 
errors are clustered at the state level. We also compute standard errors that are wild-cluster bootstrapped by state.

The coefficient of primary interest is $\beta_{1}$ which captures the differential response of FG families to expected dowry, relative to the response of FB families. The coefficient $\beta_{2}$ captures how savings in FB families respond to expected dowry receipts. The inclusion of the FG main effect allows us to control for any changes in per capita saving due to firstborn sex that could result from factors unrelated to dowry; for instance, higher fertility among FG families due to the desire for at least one son. To exclude other confounding factors related to the caste, state, gender, and year of birth of the firstborn child, we control for all main and interaction fixed effects for these factors. For instance, if certain castes are richer and therefore save more, the caste fixed effects $\left(\omega_{c}\right)$ would capture this confounding variation. If there is state or time variation in wealth status of various castes that can explain the differential saving behavior, it would be captured by the state-caste and caste-year fixed effects $\left(\phi_{c t}\right.$ and $\left.\psi_{s c}\right)$. The state-year fixed effects $\left(\pi_{s t}\right)$ take into account any differential trends across states in economic prosperity. If the fertility response to a firstborn girl differs across castes or states or time due to differential son preference, it would be captured by $\eta_{c}$ FirstGirl $_{i}, \eta_{s}$ FirstGirl $_{i}$, and $\eta_{t}$ FirstGirl $_{i}$.

Thus, any remaining threats to identification of the coefficient of interest, $\beta_{1}$, as the causal effect come from omitted caste-state-year specific factors that may be correlated with Dowr $_{\text {cst }}$ and that differentially affect FG and FB parents. To address the former concern, we replace the main effect of Dowr $y_{c s t}$ with caste $\times$ state $\times$ year fixed effects in specification (2) to estimate an even stricter specification that non-parametrically controls for everything that varies at the caste-state-year level and is correlated with household savings:

$$
\begin{aligned}
\text { Saving }_{i c s t}^{2008} & =\alpha+\beta_{1} \text { FirstGirl }_{i} \times \text { Dowry }_{c s t}+\delta_{c s t}+\beta_{3} \text { FirstGirl }_{i} \\
& +\pi_{s t}+\phi_{c t}+\psi_{s c}+\eta_{c} \text { FirstGirl }_{i}+\eta_{s} \text { FirstGirl }_{i}+\eta_{t} \text { FirstGirl }_{i} \\
& +\omega_{c}+\delta_{s}+\theta_{t}+\mathbf{X}_{i}^{\prime} \gamma+\epsilon_{i c s t}
\end{aligned}
$$

Finally, this leaves us with confounding factors that vary by caste-state-year and that differentially affect FG and FB parents. One such factor could be fertility. If dowry changes in a caste-state-year are correlated with changes in, say, the degree of son preference, the

and regress it on the observables in the listing data. These inverted predicted probabilities serve as weights, assuming that the observables capture differential reasons for being surveyed. The observables in the listing sheet data used to construct weight are household size, number of earners in the household, head's age, head's years of schooling, indicators of head's caste (SC, ST, OBC, upper caste), religion (Muslim), and gender, and state fixed effects. 
likelihood and the sex ratio of higher parity births may differ by firstborn sex. Additionally, if dowry is more prevalent in regions with stronger son preference, we would expect FG families to be more likely to have subsequent births if they are following son-biased stopping rules with or without sex-selection, and that is likely to lower per capita savings. Therefore this will bias our results in the downward direction. A higher sex ratio may eventually also reduce dowry due to the scarcity of women on the marriage market (although there is currently no evidence that this has happened in India), and, if anything, a lower expected dowry should make parents less likely to save and not more.

To address these concerns, we examine how our results change when we restrict the sample to one-child families. Since these families have not yet had a second child, any saving response to firstborn sex and expected dowry cannot be due to endogenous fertility change. ${ }^{35}$ Restricting to a short time horizon after the birth of the first child shuts down the reoptimization that takes place in response to the revelation of the first child's gender.

\subsection{Fertility and Sex Selection}

It is possible that fertility is directly affected by expected dowry if FG families respond to dowry expectations by increasing sex-selection for subsequent births (to have a compensating son who would receive dowry), which could lower fertility (and household size), and thereby lead to higher per capita savings relative to FB families. The fertility response to dowry expectations is a particularly important threat to our identification strategy. To test if this is the case, we estimate the following equation by using the number of children and the proportion of sons among second and higher parity births at the time of survey as the dependent variables:

$$
\begin{aligned}
Y_{i c s t} & =\alpha+\beta_{1} \text { FirstGirl }_{i} \times \text { Dowry }_{c s t}+\delta_{c s t}+\beta_{3} \text { FirstGirl }_{i} \\
& +\pi_{s t}+\phi_{c t}+\psi_{s c}+\omega_{c}+\delta_{s}+\theta_{t}+\mathbf{X}_{i}^{\prime} \gamma+\epsilon_{i c s t},
\end{aligned}
$$

To ensure that the results are not specific to REDS data, we also utilize rural data from the NFHS for this analysis. ${ }^{36}$ This specification is similar to specification (2), except that it excludes the interaction of FirstGirl ${ }_{i}$ with state, year, and caste fixed effects, and includes mother's and father's age and indicators for household standard of living at the time of

\footnotetext{
${ }^{35}$ Note that we implicitly take into account duration since the first birth through the year of first birth fixed effects as lack of a living child could be due to sex-selective abortion.

${ }^{36}$ NFHS interviewed women aged 15-49 (13-49 in 1992-93) at the time of the survey and obtained complete fertility histories, including the dates of live births and of any child deaths. The surveys contain information on relevant individual and household demographics.
} 
survey in the $\mathbf{X}_{i}^{\prime}$ vector. ${ }^{37}$

This analysis is also of independent interest as dowry is often cited as a cause for son preference and sex-selective behavior in India (Miller (1981), Arnold et al. (2002), Das Gupta et al. (2003), Alfano (2015), Bhalotra et al. (2016)).

\subsection{Labor Supply}

The birth of a first child can affect parents' time allocation in the following ways. As the permanent income shock due to firstborn sex is a pure lottery and does not change the reward or wage from working, there is no substitution effect. However, the income effect of future dowry implies that in the absence of credit constraints, FB parents should increase leisure (decrease labor supply) and FG parents should increase labor supply. However, if the household is credit constrained, current labor supply may not decrease for FB parents despite higher permanent income. If FG parents are income-constrained, they may also increase labor supply in an attempt to supplement their income to finance the higher savings needed for the future dowry expense. We focus on father's labor supply in this paper as 89 percent of the mothers in our dataset report being a housewife as their primary occupation. ${ }^{38}$

Using the employment history between 1986 and 2007, we estimate the labor supply response for father $i$ from caste $c$ in state $s$ in year $t^{\prime}$ and whose first child was born in year $t$ as follows:

$$
\begin{aligned}
L_{i t^{\prime}} & =\alpha+\beta_{1} \text { FirstGirl }_{i} \times \text { Post }_{t^{\prime}>t} \times \text { Dowry }_{c s t} \\
& +\beta_{2} \text { Post }_{t^{\prime}>t} \times \text { Dowry }_{c s t}+\beta_{3} \text { FirstGirl }_{i} \times \text { Post }_{t^{\prime}>t} \\
& +\delta_{s t^{\prime}}+\theta_{c t^{\prime}}+\pi_{t t^{\prime}}+\gamma_{i}+\omega_{t^{\prime}}+\epsilon_{i t^{\prime}}
\end{aligned}
$$

where $L_{i t^{\prime}}$ are the the number of days worked in year $t^{\prime}$; Post $_{t^{\prime}>t}$ equals 1 if $t^{\prime}>t$, and 0

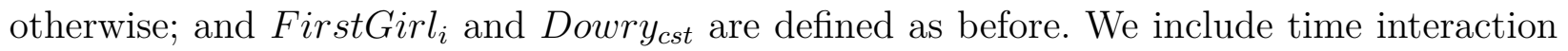
fixed effects (i.e., $\delta_{s t^{\prime}}, \theta_{c t^{\prime}}, \pi_{t t^{\prime}}$ ) as well as time fixed effects $\left(\omega_{t^{\prime}}\right)$ in this specification. The coefficient $\beta_{2}$ captures how expected dowry affects father's number of days worked after the birth of a firstborn boy and $\beta_{1}$ captures the differential response of parents of a firstborn girl after her birth. The panel nature of the labor supply variable allows us to control for father fixed effects $\left(\gamma_{i}\right)$.

\footnotetext{
${ }^{37}$ The household standard of living indicators are only available in NFHS, so they are excluded from regressions using REDS data.

${ }^{38}$ The predictions for mother's labor supply are not straightforward. While child rearing may involve some decline in market work irrespective of child gender, returns to investment of women's time in child-care on the child's marriage market may be an additional consideration while allocating time.
} 


\section{Main Results}

In this section, we first describe the impact of dowry expectations on household saving and fertility behavior. Then we examine if labor supply, debt, and consumption expenditure change in a manner that is consistent with the effect on savings. Lastly, we explore how the institution of dowry affects investments in children's human capital.

\subsection{Savings}

In Table 4 we present results from equations (1) and (2) that estimate the impact of expected future dowry payments (proxied by average current dowry payments in the marriage market) on parents' current saving behavior. Note that the expected dowry variable, unless otherwise mentioned, is in INR 10,000. We expand the definition of the savings variable as we move from column (1) to column (6). In the first two columns, we examine the effect on annual flow of per capita saving in financial institutions; in the next two columns we add annual per capita flow of cash saving to per capita flow of saving in financial institutions; and in the last two columns we also add the annual per capita flow of interest earned by the household on its savings. The coefficient of Firstborn girl is negative and always insignificant, implying that, in the absence of dowry expectations, there is no difference between the yearly per capita saving amount in FG families and FB families. However, as the interaction coefficient demonstrates, when expected dowry is positive, FG families save significantly more than FB families on a per capita annual basis, and, within FG families, per capita annual savings increase with the amount of expected dowry. The specifications without caste-state-year fixed effects show that FB families do not significantly alter per capita savings when anticipated dowry receipts are higher, as the coefficients are insignificant. These results suggest that the impending future lump-sum dowry expense induces FG families to start saving more in advance. $^{39}$

As per column (6), if expected dowry increases by INR 10,000, annual per capita savings go up by INR 617.54 in FG families, on average. For the mean level of expected dowry (=INR 26,120), FG families save INR 1,613 (=617.54*2.612) more on per capita basis each year than FB families. The results are similar if we use total annual household savings as opposed to per capita savings as the outcome variable (Appendix Table A.4). The last column of Appendix Table A.4 shows that if expected dowry increases by INR 10,000, total household savings, on average, go up by INR 3,789.41 in FG families. As we use a flow measure of per capita

${ }^{39}$ These results are driven by Hindu households (Appendix Table A.8), which is not surprising as Hindus comprise the bulk of our sample and caste is primarily, though not solely, a Hindu phenomenon. 
saving, it is reassuring that the results remain the same when we control for the stock of savings at the beginning of 2007 (column (1) of Table 5). ${ }^{40}$

To address the endogeneity concerns related to differential fertility in FG and FB families, we first show that our results survive controlling for indicators for the number of children (column (2) of Table 5). Second, in Table 6, we re-estimate the effects on savings for families that only have one child. The sub-sample of one-child families offers a strict test for our story since the saving behavior of these families has not yet been affected by the differential likelihood of higher parity births or sex-selection of these births by firstborn sex (given that we flexibly control for duration since first birth effects). Despite the small sample size, we find that families that have only a girl child save significantly more than families that have only a boy child for given expected dowry. The higher magnitude of the savings effect in Table 6 relative to Table 4 suggests that per capita savings fall as the number of children increases.

The higher savings in FG families take the form of higher per capita formal saving in financial institutions. As Table 7 shows, we do not find a significant difference in the annual flow of jewelry saving (in precious stones and metals) among FG and FB families. ${ }^{41}$ Similarly, there are no significant differences in the flow of saving in livestock (although the coefficient is positive) and saving in durable goods. One may be concerned that the lack of significant effects on these flow measures is due to the fact that purchases of durable goods are relatively infrequent. Therefore, we also examine if using the stock versions of the saving variables in Table 7 yields different results. The interaction coefficients remain insignificant, however (Appendix Table A.5).

This pattern of saving behavior is consistent with greater access to financial institutions and instruments in rural India and the less liquid nature of jewelry relative to cash savings in bank accounts during our study period. Our findings do not imply that jewelry is no longer a significant part of dowry in India. The lack of an effect on savings in jewelry simply suggests that parents do not save for future dowry through advance savings in jewelry; they may and most likely do utilize the savings in financial institutions to purchase jewelry and other items around the time of marriage.

\footnotetext{
${ }^{40}$ Ideally, like specification (3) for labor supply, we would like to use data on household savings before the birth of the first child and compare it with savings afterwards. However, 2006 REDS only reports cross-sectional information on savings. Note, however, that REDS is a panel survey, and the same households were also surveyed in 1999. Unfortunately, the survey questions were not exactly the same in both rounds, making it difficult to use the 1999 round for a panel-specification without significant measurement error.

${ }^{41}$ This is true irrespective of whether the family has only one child or more children.
} 
Back-of-the-envelope calculations suggest that FG families accumulate about INR 82,817 per daughter by the time she is 15 years old, the median age at marriage in our sample. ${ }^{42}$ According to 2005 IHDS data, an average bridal family spends INR 75,777 to INR 98,498 on a wedding in rural India. Thus, households appear to be able to save for the bulk of the wedding expenditure in advance. Any remaining shortfall is potentially met by borrowing from informal sources during the year of marriage. While our sample is too small to analyze how borrowing changes with distance from the year of marriage, it does indicate that households are more likely to borrow during the year of marriage than otherwise. The likelihood that a household applied for a loan (formal or informal) in the year before the survey is significantly higher if a marriage took place in the household during the same year than if it did not (47 percent versus 18 percent). The corresponding numbers for borrowing specifically for marriage or ornaments are 32 percent in households where a marriage took place last year versus 0.54 percent in households where no marriage occurred last year. ${ }^{43}$

\subsection{Fertility and Sex Selection}

In Table 8 we examine if dowry expectations affect childbearing and sex-selection decisions, and whether this effect differs by firstborn sex, by estimating specification (2) using NFHS data. We prefer using NFHS for this analysis as it reports birth history for each mother where as in REDS we need to impute it from children's ages. Moreover, NFHS is substantially larger in sample size than REDS. Nonetheless, we also report the corresponding results from REDS data in Appendix Table A.6. The coefficients of Firstborn girl in Table 8 imply that FG families have more children and practice greater sex-selection at second and higher parities even if expected dowry is zero. The interaction coefficients are, however, always insignificant, implying that there is no differential effect of dowry by firstborn sex on future childbearing and sex-selection. We find similar results with REDS data in Appendix Table A.6.

These findings not only assuage concerns about endogenous fertility, but are also important in their own right. It is frequently claimed that dowry is an underlying cause of son preference, male-biased fertility, and discrimination against girls in India. Bhalotra et al. (2016), for instance, find that an unexpected one-time increase in the price of gold led to immediate rise in fetal and infant mortality of girls presumably because households perceived

\footnotetext{
${ }^{42}$ The average household size in our sample is 5.78. Thus, for the mean level of expected dowry (=INR 26,120), FG families accumulate INR 89,653 more than FB families over 15 years $(=395.89$ * $2.612 * 5.78 * 15)$. Since FG families have 1.09 more girls than FB families, this implies that FG families save roughly INR 82,251 per daughter.

${ }^{43}$ The average likelihood of borrowing in the year before the survey is 19 percent for any loan and 1.49 percent for loan for marriage or ornaments.
} 
the gold price shock as an increase in the value of dowry. Similarly, Alfano (2015) finds that an amendment that made the Indian anti-dowry law stricter in 1985 led to decreases in male-biased fertility behaviors as it potentially made the dowry cost of daughters smaller. Our findings do not support the results in Alfano (2015) and Bhalotra et al. (2016); however, both do not directly estimate the effect of dowries on their outcomes of interest. If dowry indeed causes male-biased behaviors, by the same reasoning, FG families should also be more likely to practice sex-selection at higher parities as expected dowry rises. However, we do not find this to be the case.

While the desire for at least one son is real, and affects childbearing decisions in India (Jayachandran (2015), Jayachandran (2017)), we find that it leads to higher fertility and higher sex ratios even in the absence of dowry, but dowry does not seem to be an additional significant explanatory factor. This finding is reasonable for the following reason. If dowry expenditure was the predominant reason for sex-selective behavior, one would expect parents to always prefer a son over a daughter, irrespective of birth parity and sex-composition of other children, since all daughters require a dowry. However, the pattern of son preference and sex-selection in India is highly parity-specific and depends on the number of sons a family has. Indian parents seem to strongly desire one son, and conditional on having at least one son, stated preferences are quite gender neutral. ${ }^{44}$ The bulk of sex-selective abortions take place is families that do not have a son. Thus, consistent with our findings, dowry is unlikely to be the root cause of sex-selective behavior.

\subsection{How are savings financed?}

Next we test if FG families make adjustments to consumption expenditure, labor supply, and debt to finance the higher per capita savings we observe above. The ability of households to save crucially depends on the income and credit constraints they face and how close they are to subsistence consumption. Table 9 shows that the dowry-induced increase in savings in FG families is driven by above poverty line (APL) households. The coefficient of Firstborn girl * Expected dowry is also positive for BPL families but is small and insignificant, suggesting that poor parents' ability to save in advance for future dowry is limited by the constraints they face.

For consumption expenditure, the coefficient of Firstborn girl in Appendix Table A.7 is negative and often significant suggesting that FG families consume significantly less per

\footnotetext{
44 The emphasis on having one son is likely due to the lack of institutional old-age support (Ebenstein and Leung (2010)) and cultural norms such as patrilocality (Ebenstein (2014)) and male-centered funeral rituals.
} 
capita than FB families even when dowry is not a consideration. This could be because FG families have more children than FB families and thus have more household members. But the interaction term is never significant, implying that there is no differential impact of expected dowry on consumption in both APL and BPL households.

Using annual days worked as a measure of labor supply, we find that FG parents attempt to finance the higher savings through higher earnings. Column (1) in Table 10 shows that greater future dowry expenditure causes FG fathers to work more relative to FB fathers after the birth of their first child; the latter do not exhibit a significant change in their annual labor supply. Note that, in the absence of dowry expectations, FG fathers do not work more than FB fathers after their first child is born. For mean expected dowry (=INR 26,120), the triple-interaction coefficient $(=3.64)$ translates into roughly 10 more FG father's days worked each year relative to his labor supply before the daughter's birth and relative to FB fathers. The average daily wage for agricultural casual labor in our data is INR 61 and, for non-agricultural casual labor, it is INR 91. Assuming that fathers are able to earn these wages for the extra days worked, their income increases by INR 610 to INR 910 each year relative to their pre-first child income and relative to FB families. Consistent with the savings results, the increase in father's labor supply is larger for APL households as compared to BPL families for whom the effect is insignificant. Although the increase in labor income is significant, it is smaller than the increase in savings we observe in Table 4. It is quite possible that households have other sources of income that we do not observe in our data. For instance, later we show that brothers in FG families decrease years of schooling due to expected dowry; this may be because they also increase their labor supply to supplement their fathers' earnings to finance the increased savings.

In Table 11, we examine if there is also a corresponding rise in debt for FG families relative to FB families due to expected dowry. Column (1) shows that for average expected dowry (=INR 26,120), FG families are 6 percentage points more like to have borrowed the year before the survey, although we lose significance once caste-state-year fixed effects are included. In the absence of dowry expectations, FG families are less likely to have borrowed than FB families. Each INR 10,000 rise in expected dowry raises the likelihood of borrowing by 3 percentage points for FG families. However, we have very little information to be able to credibly estimate the effect on the amount borrowed by FG families to finance future dowry.

On the whole, we find that FG families finance the increased savings after the birth of their daughter by increasing fathers' labor supply and by borrowing somewhat more. 


\subsection{Children's health and education}

So far we have shown that having to pay for a daughter's dowry does not affect fertility or sex-selective behavior. Now, we examine whether dowry expectations impact investments in and outcomes of children, and if so, whether these effects differ by child gender.

There is little empirical research on the effect of marriage payments on child investments, with the exception of Ashraf et al. (2016) who compare societies with and without bride price and show that the custom of bride price provides a greater incentive for parents to invest in girls' education. More educated daughters fetch a higher bride price, thus increasing the return to parents from investing in their education. However, dowry is not simply negative bride price. While a bride's parents have property rights over the bride price, in the case of dowry, the bride and her husband may share property rights along with the groom's parents. In fact, historically dowry was a pre-mortem bequest to daughters (known as stridhan $){ }^{45}$ Thus, in dowry-paying societies, the relationship between child investments and dowry may be more complicated than in the context of bride price.

If households are budget constrained, parents of daughters face a trade-off between saving for her dowry and investing in her and her siblings' health and education. A crucial factor in parents' decision-making would be the returns to female education on the marriage and labor markets. If a better educated bride is more valuable to the groom's family due to either her income generating potential (if returns to female education are sufficiently high on the labor market) or due to improvements in grandchild quality, more educated brides may have to pay lower dowries, and natal families may invest in female education rather than save for dowry (Anderson (2014)). Thus, in principle, parents could recover their investment in their daughter's health and education in the form of lower dowry demands or a higher-quality son-in-law.

However, female labor force participation is quite low in India due to relatively restricted economic opportunities for women (Fletcher et al. (2017), Afridi et al. (2016)); therefore female education may not have high perceived returns on the labor market. Unless the groom's family highly values an educated bride for her ability to have high quality children, ${ }^{46}$ it may be unlikely that more educated brides pay lower dowry. Appendix Figure A.1 shows that more educated brides, in fact, pay higher dowry on average. While this positive bride education-dowry relationship could be due to assortative matching on education in the

\footnotetext{
${ }^{45}$ Interestingly, the ancient Hindu text Manusmriti denounces marriages where bride price is paid (referred to as asura marriages) because it amounts to "trafficking of the daughter" and the resulting "greed can corrupt the selection process of the groom" (Olivelle (2004), Pandey (2013)).

${ }^{46}$ Such aspects of bridal quality may also not be fully observable by the groom or his family.
} 
marriage market (Appendix Figure A.3) or due to lower demand for more educated brides driven by their undesirably higher age at marriage, it remains strongly significant even after we control for bride's age at marriage and groom's years of education (Appendix Table A.9).

Thus, saving for and paying a higher dowry for a groom with better economic prospects could be more worthwhile for parents of a girl than investing in the daughter's human capital. In fact, if groom quality improves more than bride quality over time, then competition for higher quality grooms may lead to bridal families making even greater dowry payments to the groom at the expense of direct investment in their daughter's education (Anderson and Bidner (2015)). This is confirmed in Appendix Figure A.1 and Appendix Table A.9 which show that more educated grooms receive higher dowry. Our main finding that savings go up with expected dowry payments is consistent with this scenario. Note, however, that greater savings may not necessarily come at the expense of child investments as households are able to somewhat relax the budget constraint by working more and borrowing more. Nevertheless, as we do observe an increase in savings, we check if dowry expectations worsen the health status and educational attainment of children, especially of girls, in FG families relative to FB families.

For child $i$ of birth-order $b$ born in household $j$, caste $c$, in state $s$ and year $T$ and whose oldest sibling was born in year $t$, we estimate the following specification for various measures of child health outcomes using NFHS data:

$$
\begin{aligned}
Y_{i j c s t}= & \alpha+\beta_{1} \text { Firstgirl }_{j} \times \text { Dowry }_{c s t} \\
& +\delta_{c s t}+\pi_{s t}+\phi_{c t}+\psi_{s c}+\eta_{c} \text { Firstgirl }_{j}+\eta_{s} \text { Firstgirl }_{j}+\eta_{t} \text { Firstgirl }_{j} \\
& +\rho_{b t}+\beta_{2} \text { Firstgirl }_{j}+X_{j} \gamma+\omega_{c}+\delta_{s}+\theta_{t}+\kappa_{b}+\psi_{T}+\epsilon_{i c s t}
\end{aligned}
$$

This specification is similar to specification (2), except that it also includes fixed effects for birth year of the child $\left(\psi_{T}\right)$, birth order $\left(\kappa_{b}\right)$, and birth order x year of birth $\left(\rho_{b t}\right)$. Table 12 presents estimates for the likelihood that a child is wasted, is stunted, is underweight, and was low birthweight using NFHS data. The interaction coefficient compares the outcomes for children (separately for boys and girls) born in a FG versus FB family and examines if the differential response varies with the expected dowry amount. In all columns, there is no significant differential effect of expected dowry by firstborn sex. We also pool the sample of girls and boys, and find similar results.

Additionally, in Table 13, we study the differential effect of dowry expectations by firstborn sex on years of schooling of boys and girls in NFHS-3. ${ }^{47}$ The specification is similar

\footnotetext{
${ }^{47}$ We are unable to match the household member roster of NFHS- 1 and 2 with the respective
} 
to specification (2), except for the inclusion of child age fixed effects here. ${ }^{48}$ The interaction coefficients are always insignificant for girls; this suggests that dowry primarily results in higher savings and parents do not necessarily invest more in their daughter's health and education in the hope of a lower dowry demand in the future. However, there is a negative effect on boys' education in FG families. Column (2) implies that each INR 10,000 increase in expected dowry results in a 0.054 or a 1.8 percent decrease in years of schooling for boys in FG families. Consistent with our savings results, the negative effect on FG boys' education is driven by the relatively wealthier medium- and high-standard of living index families (in column (4)). It is possible that, along with FG fathers, FG brothers also work more outside the home or on household farm and businesses (and hence have less education) in order to finance the higher savings.

\section{Robustness Checks}

In this section, we discuss several robustness checks that support our key findings.

\subsection{Alternate Definitions of Expected Dowry}

In our main analysis, we proxy for dowry expectations with the average net dowry paid by brides or received by grooms from the same caste and state as the child and who married during the year of the child's birth or the prior four years. Now, we examine the sensitivity of our estimates to alternative definitions of expected dowry.

First, we reconstruct the expected dowry variable by incorporating both religion and caste directly in the definition of the marriage market. ${ }^{49}$ Specifically, we split Hindus by caste and use other religions as it is (i.e., our seven groups are: Hindu SCs, Hindu STs, Hindu OBCs, Hindu OCs, Muslims, Sikhs, Other religions) and then separately define expected dowry for these groups (while using state and year of birth as before). ${ }^{50}$ Column (1) of Table A.10 shows that our savings results are robust to this alternate definition of expected dowry.

Second, instead of using the average of net dowries paid in marriages that occurred during the year of the child's birth (YOB) or the prior four years, in column (2) of Table A.10 we use the average of net dowries paid around the YOB of the child (i.e., during $Y O B+2, Y O B+$

\footnotetext{
mother's datasets.

${ }^{48}$ Note that in these regressions we can either include caste-state-year fixed effects or the firstborn girl interaction fixed effects due to estimation issues. In Table 13 we include caste-state-year fixed effects but exclude firstborn girl interaction fixed effects.

${ }^{49}$ In the main analysis, we incorporate religious heterogeneity by controlling for religion dummies in the regressions.

${ }^{50}$ Hinduism is the majority religion in India, and although other religions also exhibit caste, our sample size prevents us from splitting non-Hindus into further groupings by caste.
} 
1, $Y O B, Y O B-1, Y O B-2)$. Once again, the interaction coefficient remains positive and statistically significant.

Finally, we show the robustness of the main results using median dowry (instead of average dowry) to proxy for expected dowry in Table A.11. The point estimates of the interaction coefficient are similar in magnitude to Table 4 (our main table for the savings results), but we lose significance in column (6) of Table A.11. Table A.12 shows that results for father's labor supply are also robust to using the median to define expected dowry.

\subsection{Missing Observations}

In 2006 REDS, we observe 17,401 marriages for which the year of marriage is available and is during 1986-2007. In the analysis so far, we have excluded marriages where data on both gifts given and received is missing (209 observations). Among the rest, while 8,128 (47.28 percent) observations have information on both gifts, the remaining 9,064 (52.72 percent) have one of them missing. In the latter case, when only one of the two is missing, we have calculated net dowry by assuming that the missing value equals zero. In doing so (i.e., by replacing missing data with zeros), we are primarily underestimating gifts from the groom's side, and in turn overestimating net dowry, since in 96.22 percent of the cases where one of the gifts is missing, the missing data is for gifts from the groom's side. Therefore, we test if our findings are driven by our treatment of missing data. ${ }^{51}$ Reassuringly, our results remain the same if we construct expected dowry by only using marriages where both gifts are non-missing (see column (3) of Table A.10).

\subsection{Expected Gross Marriage Payments}

Like most other papers on dowry in economics, we have modeled dowry as net dowry, following Becker (1981). However, gross payments from the bride's family may be more relevant in explaining the saving behavior as the bridal family must incur its share of the gross expenditure in advance and before receiving the payments from the groom's side during the marriage. We check how replacing net dowry with its two component variables, i.e., gross payments by the bride's and by the groom's family in specification (2) alters the impact on savings. Since payments by the groom are much smaller than those by the bride, we do not expect this to matter. Table A.13 confirms our intuition. The coefficient of Firstborn girl

* Expected gross payment by bride continues to be positive and significant, and similar in magnitude to the coefficient of Firstborn girl * Expected net dowry in Table 4.

\footnotetext{
${ }^{51}$ We discuss missing observations in more detail in Appendix B.
} 


\subsection{Dropping one state at a time}

Lastly, we test the sensitivity of our savings and father's labor supply results to the inclusion of any one particular state by re-estimating specifications (2) and (3) while dropping one state at a time. The coefficients for the main interaction terms are reported in Table A.14. It is reassuring that the magnitude of the coefficients remains similar to our previous estimates. Moreover, out of 34 regressions, we lose significance only in three cases.

\section{Conclusion}

A large literature has shown that culture matters for economic outcomes. More narrowly, there is a small but emerging body of work that highlights the importance of marriagerelated cultural norms and institutions for households' decision-making. Despite the wide prevalence of bride-to-groom marriage payments, i.e., dowries, in several developing countries, economists have not directly investigated their impacts on financial and childbearing decisions, and on human capital investments in children. This is due to both the lack of data on dowry and the lack of a credible identification strategy. In this paper, we make use of an under-utilized source of nationally representative dowry data from India and propose a novel estimation strategy to examine the impact of future dowry payments on current outcomes.

We find several important results. This is the first paper, that we are aware of, that proposes an alternative motive for savings behavior in dowry-paying societies: the prospect of lump-sum dowry expense induces firstborn-girl families to start saving more in advance relative to firstborn-boy families in rural India. The ability of parents to overcome barriers to savings, especially behavioral biases such as imperfect self-control, in the context of saving for dowry, suggests that it is crucial to take into account the cultural context while designing policies that seek to affect saving behavior. We find that the increased savings take the form of formal savings in financial institutions and not savings in jewelry or precious metals that are traditionally considered an integral part of the dowry in India. The higher savings that we find are financed through higher earnings; fathers of firstborn girls work more days in a year relative to FB fathers as expected dowry burden goes up. We also find that brothers in FG families decrease their years of schooling as expected dowry expenditure goes up, suggesting that they may also be working more in order to finance higher savings for their sisters' dowry.

In the context of India, it is frequently claimed that dowry is an underlying cause of son preference, male-biased fertility, and discrimination against girls. Contrary to this, we find that dowry is unlikely to be a root cause of son-preferring behaviors in India. Finally, we do not find any evidence that dowry expectations have an impact on girls' human capital 
investments - a relationship on which no previous evidence is available.

Future research should examine if the results of this paper also hold true for urban India and for other dowry-paying societies. How alternate marriage market institutions, such as bride price, affect households' financial decisions also remains a fruitful area for future research.

\section{References}

Abrevaya, J. (2009): "Are There Missing Girls in the United States? Evidence from Birth Data," American Economic Journal: Applied Economics, 1, 1-34.

Afridi, F., T. Dinkelman, and K. Mahajan (2016): "Why Are Fewer Married Women Joining the Work Force in India? A Decomposition Analysis over Two Decades," Technical report, IZA.

Alfano, M. (2015): "Daughters, Dowries, Deliveries: The Effect of Marital Payments on Fertility Choices in India," CReAM Discussion Paper.

Almond, D. And L. Edlund (2008): "Son Biased Sex Ratios in the US 2000 Census," Proceedings of the National Academy of Sciences of the United States of America, 105, 5681-5682.

Ambrus, A., E. Field, And M. Torero (2010): "Muslim Family Law, Prenuptial Agreements, and the Emergence of Dowry in Bangladesh," Quarterly Journal of Economics, $125,1349-1397$.

Anderson, S. (2007): "Why the Marriage Squeeze Cannot cause Dowry Inflation," Journal of Economic Theory, 137, 140-152.

(2014): "Human Capital Effects of Marriage Payments," IZA World of Labor, 77.

Anderson, S. And C. Bidner (2015): "Property Rights over Marital Transfers," The Quarterly Journal of Economics.

Anukriti, S., S. Bhalotra, and H. Tam (2016): "On the Quantity and Quality of Girls: New Evidence on Abortion, Fertility, and Parental Investments," IZA Discussion Paper.

Arnold, F., S. Kishor, And T. Roy (2002): "Sex-selective Abortions in India," Population and Development Review, 28, 759-785.

Ashraf, N., N. Bau, And A. Voena (2016): "Bride Price and Female Education," NBER Working Paper.

Banerjee, A., E. Duflo, M. Ghatak, And J. Lafortune (2013): "Marry for What? Caste and Mate Selection in Modern India," American Economic Journal: Microeconomics, $5,33-72$.

Becker, G. (1981): “A Treatise on the Family," Harvard University Press.

Bhalotra, S., A. Chakravarty, And S. Gulesci (2016): "The Price of Gold: Dowry and Death in India," IZA Discussion Paper 9679. 
Bhalotra, S. And T. Cochrane (2010): "Where Have All the Young Girls Gone? Identification of Sex Selection in India," IZA Discussion Paper No. 5381.

Bhalotra, S. and A. van Soest (2008): "Birth-Spacing, Fertility and Neonatal Mortality in India: Dynamics, Frailty, and Fecundity," Journal of Econometrics, 143, 274-290.

Bloch, F. AND V. RaO (2002): "Terror as a Bargaining Instrument: A Case Study of Dowry Violence in Rural India," American Economic Review, 92, 1029-1043.

Borker, G., J. Eeckhout, N. Luke, S. Minz, K. Munshi, and S. Swaminathan (2017): "Wealth, Marriage, and Sex Selection," .

Botticini, M. And A. Siow (2003): "Why Dowries?" American Economic Review, 93, $1385-1398$.

Campbell, J. Y. (1987): "Does Saving Anticipate Declining Labor Income? An Alternative Test of the Permanent Income Hypothesis," Econometrica, 55, 1249-73.

Chiplunkar, G. And J. Weaver (2017): "Marriage Markets and the Rise of Dowry in India," Working Paper.

Clark, S. (2000): "Son Preference and Sex Composition of Children: Evidence from India," Demography, 37, 95-108.

Corno, L., N. Hildebrandt, And A. Voena (2017): "Age of Marriage, Weather Shocks and the Direction of Marriage Payments," Working Paper.

Das Gupta, M. And P. Bhat (1997): "Fertility Decline and Increased Manifestation of Sex Bias in India," Population Studies, 51, 307-315.

Das Gupta, M., J. Zhenghua, L. Bohua, X. Zhenming, W. Chung, and B. HwaOK (2003): "Why is Son Preference So Persistent in East and South Asia? A Cross-country Study of China, India and the Republic of Korea," Journal of Development Studies, 40, $153-187$.

DellaVigna, S. (2009): "Psychology and Economics: Evidence from the Field," Journal of Economic Literature, 47, 315-372.

Deolalikar, A. And E. Rose (1998): "Gender and Savings in Rural India," Journal of Population Economics, 11, 453-470.

DU, Q. AND S.-J. WEI (2013): "A theory of competitive saving motive," Journal of International Economics, 91, 275-289.

Ebenstein, A. (2014): "Patrilocality and Missing Women," .

Ebenstein, A. And S. Leung (2010): "Son preference and access to social insurance: evidence from China's rural pension program," Population and Development Review, 36, $47-70$.

Edlund, L. (2006): "The Price of Marriage: Net vs. Gross Flows and the South Asian Dowry Debate," Journal of European Economic Association, 4, 542-551.

Fletcher, E. K., R. Pande, And C. T. Moore (2017): "Women and Work in India: Descriptive Evidence and a Review of Potential Policies," Working Paper. 
Franco, M. And R. H. Brumberg (1954): "Utility Analysis and the Consumption Function: An Interpretation of Cross-Section Data," In Post-Keynesians Economics, ed. K Kurihara. New Brunswick: Rutgers University Press, 388-436.

Franklin, M. (2017): Boccaccio's Heroines: Power and Virtue in Renaissance Society, Routledge, London and New York.

Frick, C. C. (2011): Dressing Renaissance Florence: Families, Fortunes, and Fine Clothing, JHU Press.

Friedman, M. (1957): "A Theory of the Consumption Function," Princeton, NJ: Princeton University Press.

Grossbard, S. (2015): "Savings, Marriage, and Work-in-Household," The Marriage Motive: A Price Theory of Marriage, in Springer Publishing.

HoriokA, C. Y. (1987): "The Cost of Marriages and Marriage-related Saving in Japan," Kyoto University Economic Review, 57, 47-58.

Horioka, C. Y. And A. Terada-Hagiwara (2016): "The Impact of Pre-marital Sex Ratios on Household Saving in Two Asian Countries: The Competitive Saving Motive Revisited," NBER Working Paper.

JAPpelli, T. AND L. PistaferRi (2010): "The Consumption Response to Income Changes," Annual Review of Economics, 2, 479-506.

JAYACHANDRAN, S. (2015): "The Roots of Gender Inequality in Developing Countries," Annual Review of Economics, 7, 63-88.

(2017): "Fertility Decline and Missing Women," American Economic Journal: Applied Economics, 9, 118-139.

Jensen, R. (2012): "Another Mouth to Feed? The Effects of Fertility on Girls' Malnutrition," CESifo Economic Studies, 58, 322-47.

Karlan, D., A. L. Ratan, And J. Zinman (2014): "Savings by and for the Poor: A Research Review and Agenda," Review of Income and Wealth, 60, 36-78.

Kugler, A. D. And S. Kumar (2017): "Preference for Boys, Family Size, and Educational Attainment in India," Demography, 54, 835-859.

Logan, T. D. And R. Arunachalam (2014): "Is there Dowry Inflation in South Asia," Historical Methods, 47, 81-94.

Maertens, A. (2013): "Social Norms and Aspirations: Age of Marriage and Education in Rural India," World Development, 47, 1-15.

Milazzo, A. (2017): "Why Are Adult Women Missing? Son Preference and Maternal Survival in India," Working Paper.

Miller, B. D. (1981): The Endangered Sex: Neglect of Female Children in Rural North India, Cornell University Press.

Moorjani P., Thangaraj K., P. N. L. M. L. P.-R. G. P. E. A. (2013): "Genetic Evidence for Recent Population Mixture in India," American Journal of Human Genetics, 93, 422-438. 
Morduch, J. (1995): "Income Smoothing and Consumption Smoothing," Journal of Economic Perspectives, 9, 103-114.

Olivelle, P. (2004): The Law Code of Manu, Oxford University Press.

Pandey, R. (2013): Hindu Samskaras: Socio-Religious Study of the Hindu Sacraments, Motilal Banarasidass, 10 ed.

RAO, V. (1993): "The Rising Price of Husbands: A Hedonic Analysis of Dowry Increases in Rural India," Journal of Political Economy, 101, 666-77.

REDS (2006): "Rural Economic and Demographic Survey," National Council of Applied Economic Research.

Rose, E. (2000): "Gender Bias, Credit Constraints and Time Allocation in Rural India," Economic Journal, 110, 738-758.

Rosenblum, D. (2013): "The effect of fertility decisions on excess female mortality in India," Journal of Population Economics, 26, 147-180.

Roy, S. (2015): "Empowering Women? Inheritance Rights, Female Education and Dowry Payments in India," Journal of Development Economics, 114, 233-251.

Sekhri, S. And A. Storeygard (2014): "Dowry Deaths: Response toWeather Variability in India," Journal of Development Economics, 111, 212-223.

Strathern, P. (2015): Death in Florence: The Medici, Savonarola, and the Battle for the Soul of a Renaissance City, Pegasus Books.

Tertilt, M. (2005): "Polygyny, Fertility, and Savings," Journal of Political Economy, 113, $1341-1371$.

VisAria, L. (2005): "Female Deficit in India: Role of Prevention of Sex Selective Abortion Act," mimeo.

Wei, S.-J. And X. Zhang (2011): "The Competitive Saving Motive: Evidence from Rising Sex Ratios and Savings Rates in China," Journal of Political Economy, 119, 511-564. 


\section{$7 \quad$ Figures and Tables}

Figure 1: Real marriage payments (in INR), by year of marriage
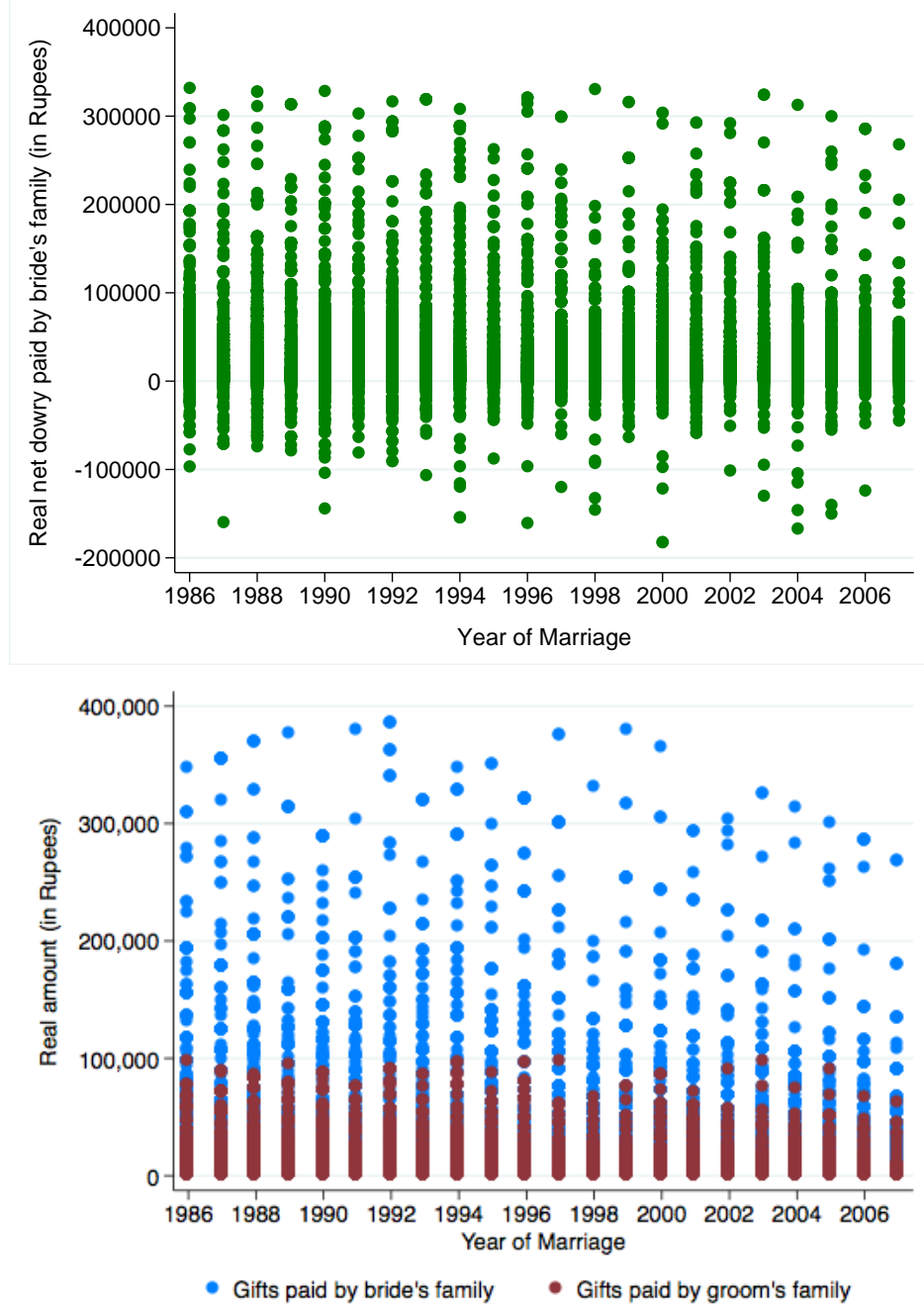

NOTES: The top figure plots the raw data on the real net dowry paid by the bride's family for all marriages in our data that took place during 1986-2007, by year of marriage. Each dot denotes a marriage. The bottom graph distinguishes between the real value of the gifts from the bride's family and from the groom's family. 
Figure 2: Distribution of marriage payments (in INR)
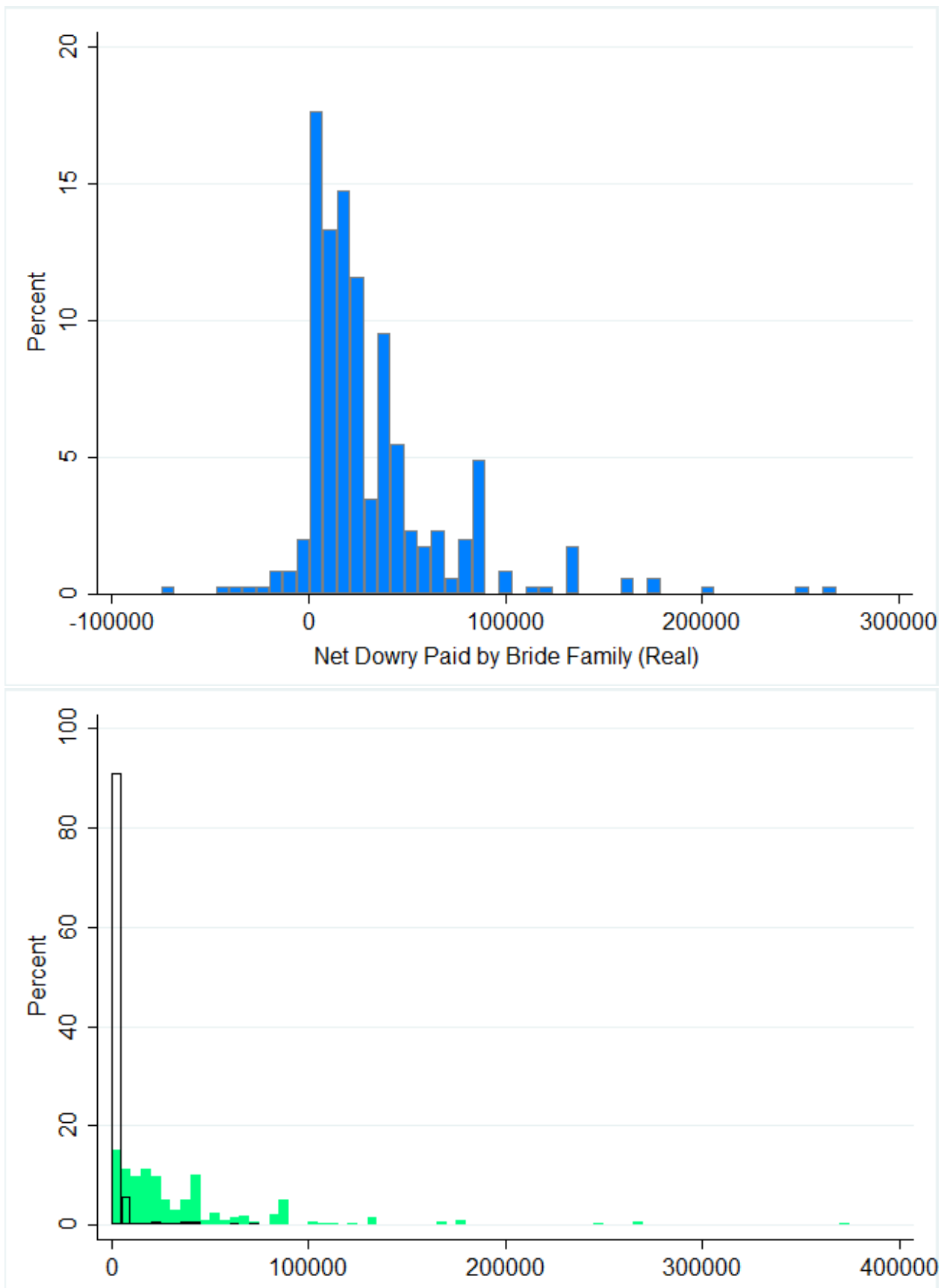

\begin{tabular}{|l|l}
\hline Gifts from bride's family $\square$ Gifts from groom's family \\
$\square$
\end{tabular}

NOTES: This figure plots the distribution of net dowry (in the top figure) and the distribution of gross payments by the bride's and the groom's families (in the bottom figure) for all marriages in our data that took place during 1986-2007. 
Figure 3: Correlation between expected and actual dowry

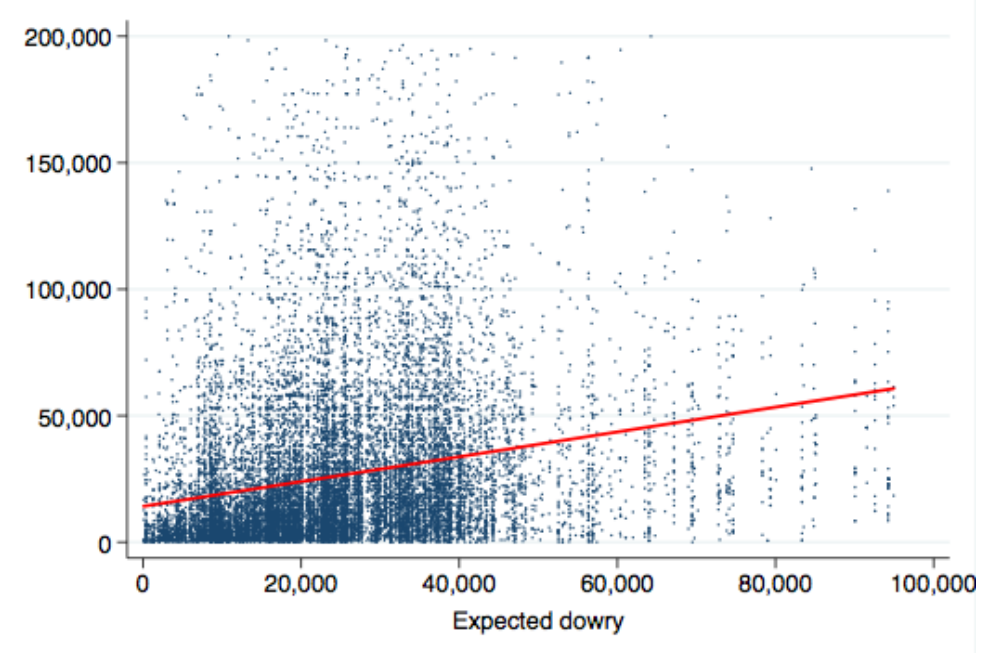

Net dowry paid by bride's family (Real) _ _ Fitted values

NOTES: This figure shows how our expected dowry variable (defined as the average net dowry paid (received) by brides (grooms) from the same caste and state as the child and who married during the year of the child's birth or the prior four years) covaries with actual dowry. This figure is based on the sample of individuals in 2006 REDS whose year of birth and year of marriage span our dowry data. The sample is restricted to observations where expected dowry $\in(0,100000)$ and actual dowry $\in(0,200000)$ to prevent outliers from biasing the figure.

Figure 4: Our expected dowry variable (in INR), by year of birth of the firstborn child

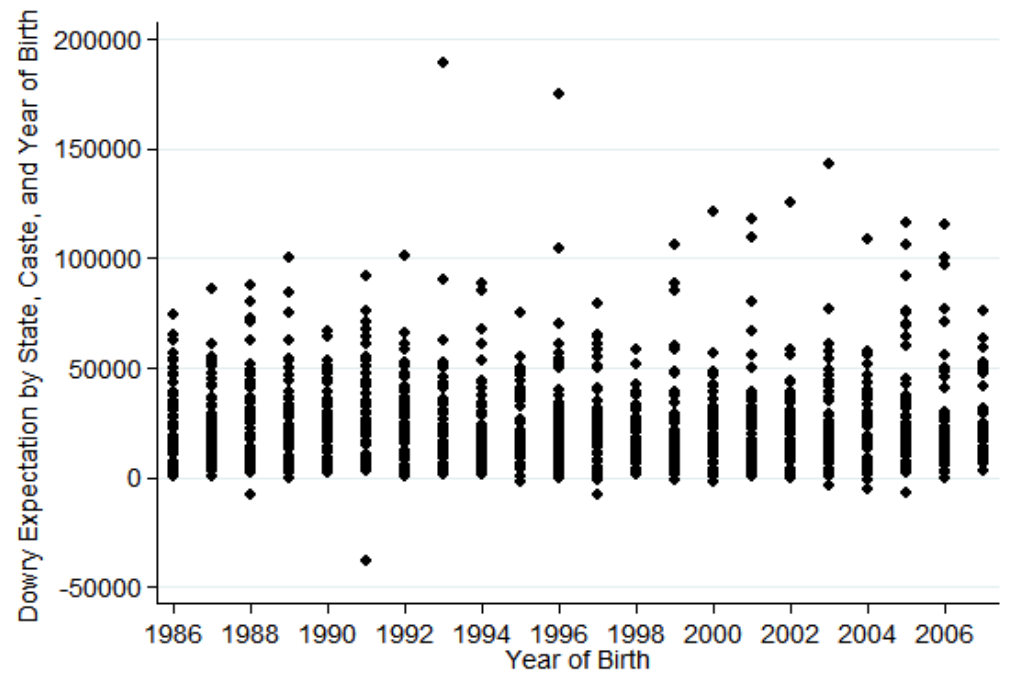

NOTES: This figure plots our expected dowry variable, by year of birth of the firstborn child. Each dot denotes a caste-state cell. In this graph, we remove a few outlier cells where expected dowry is greater than INR 200,000. 
Figure 5: Our expected dowry variable (in INR), by year of birth of the firstborn child and caste
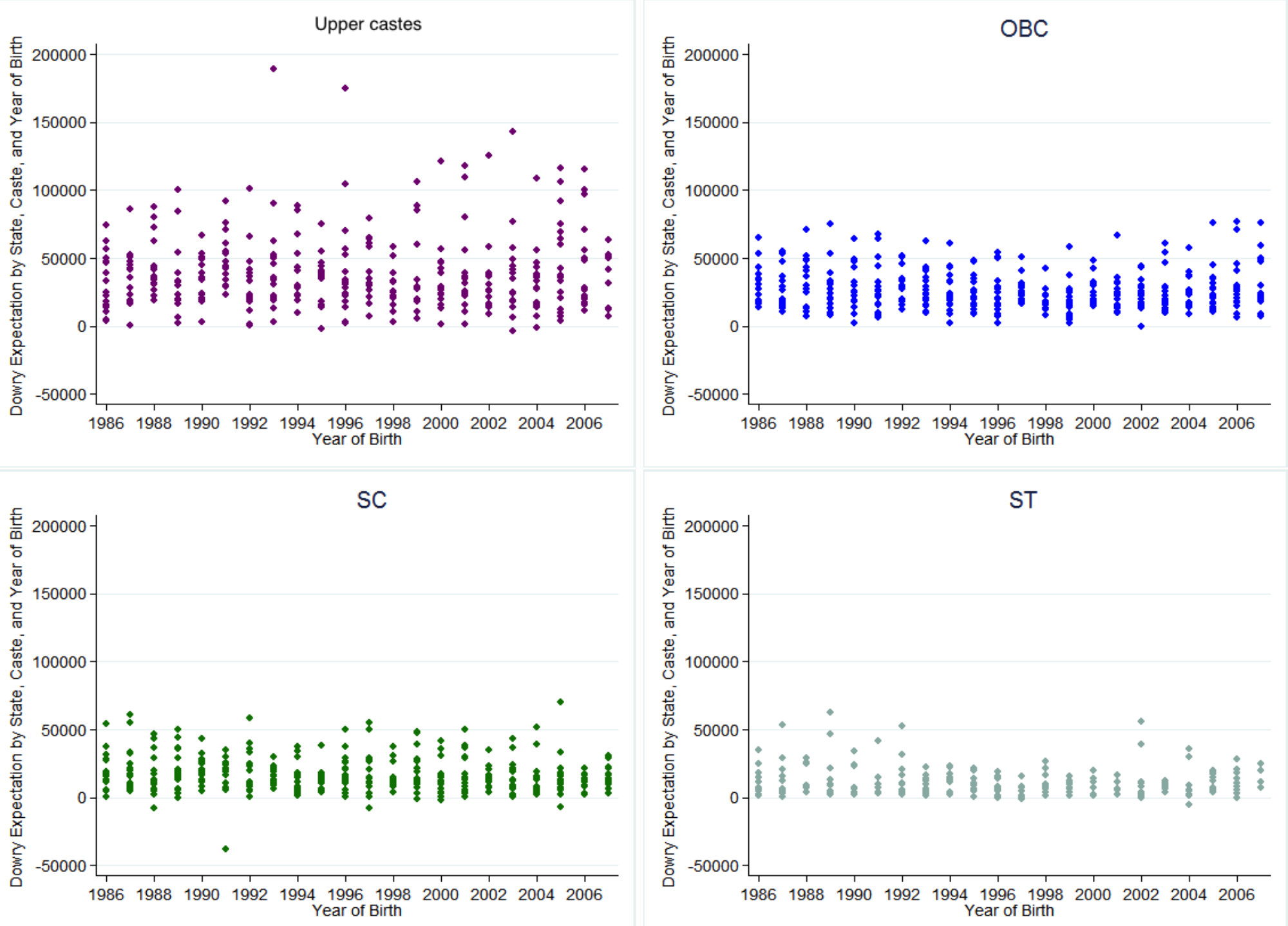

NOTES: This figure plots our expected dowry variable by year of birth of the firstborn child, separately for each caste group. OBC, SC, and ST stand for other backward classes, scheduled castes, and scheduled tribes, respectively. In this graph, we remove a few outlier cells where expected dowry is greater than INR 200,000. 
Figure 6: Distribution of per capita savings in financial institutions (in INR)

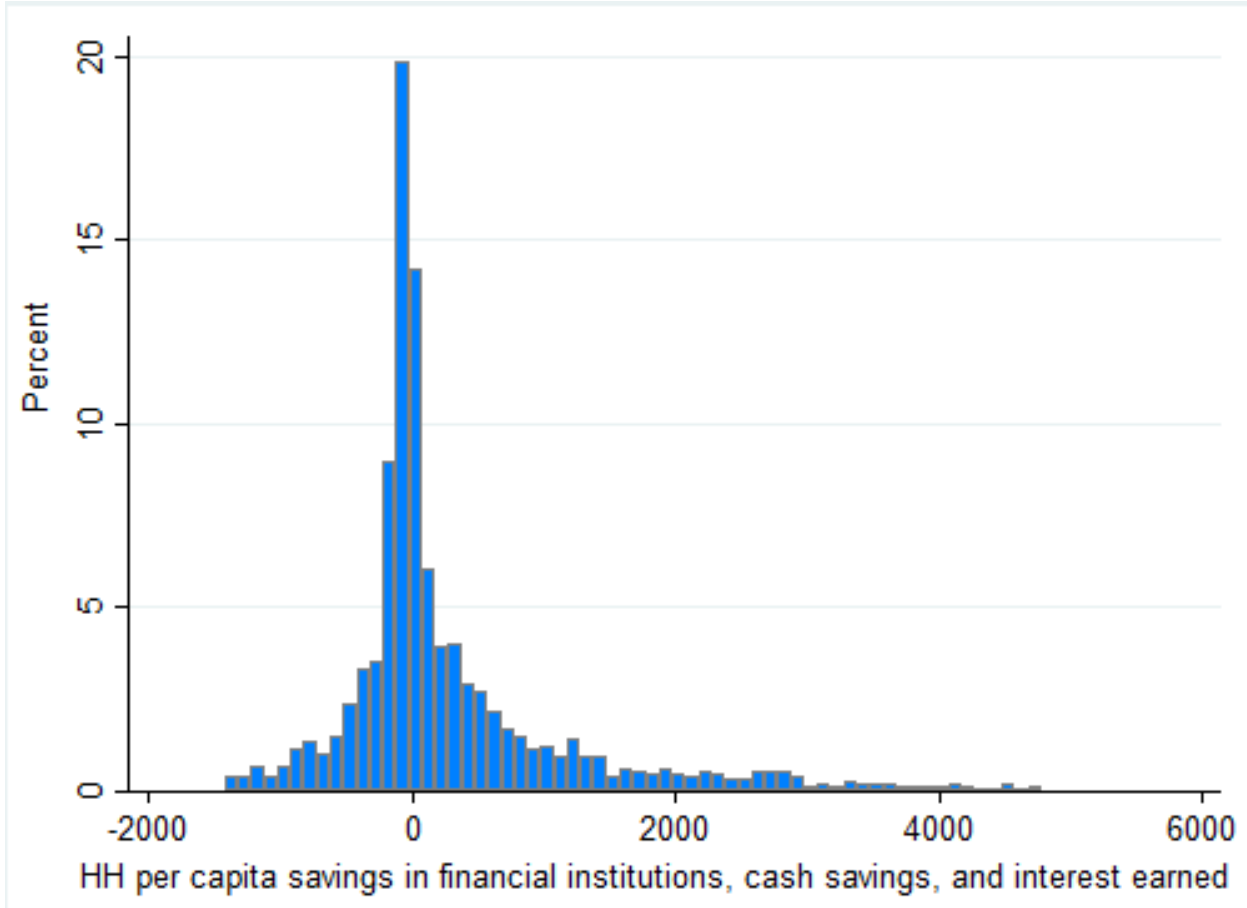

NOTES: This figure plots the distribution of the flow of per capita household savings in financial institutions, cash savings, and interest earned during 2007 as reported in 2008 (in 2005 INR). 
Figure 7: State-wise average per capita savings in financial institutions (in INR)
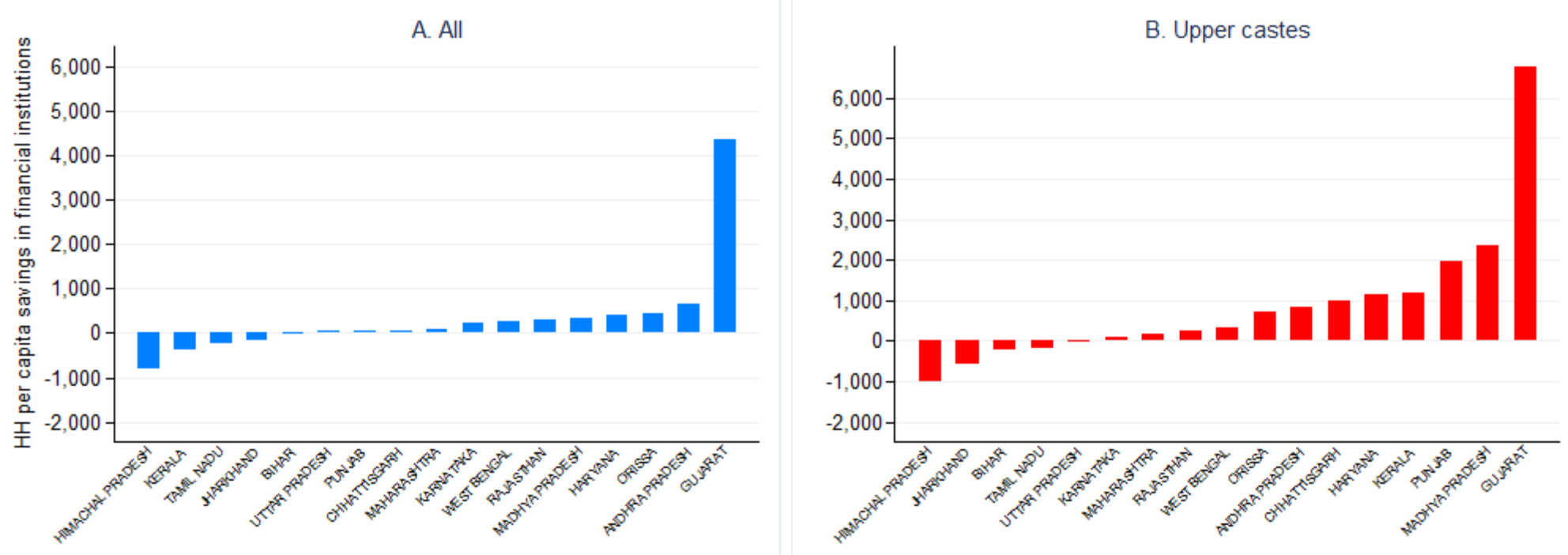

C. $\mathrm{OBC}$
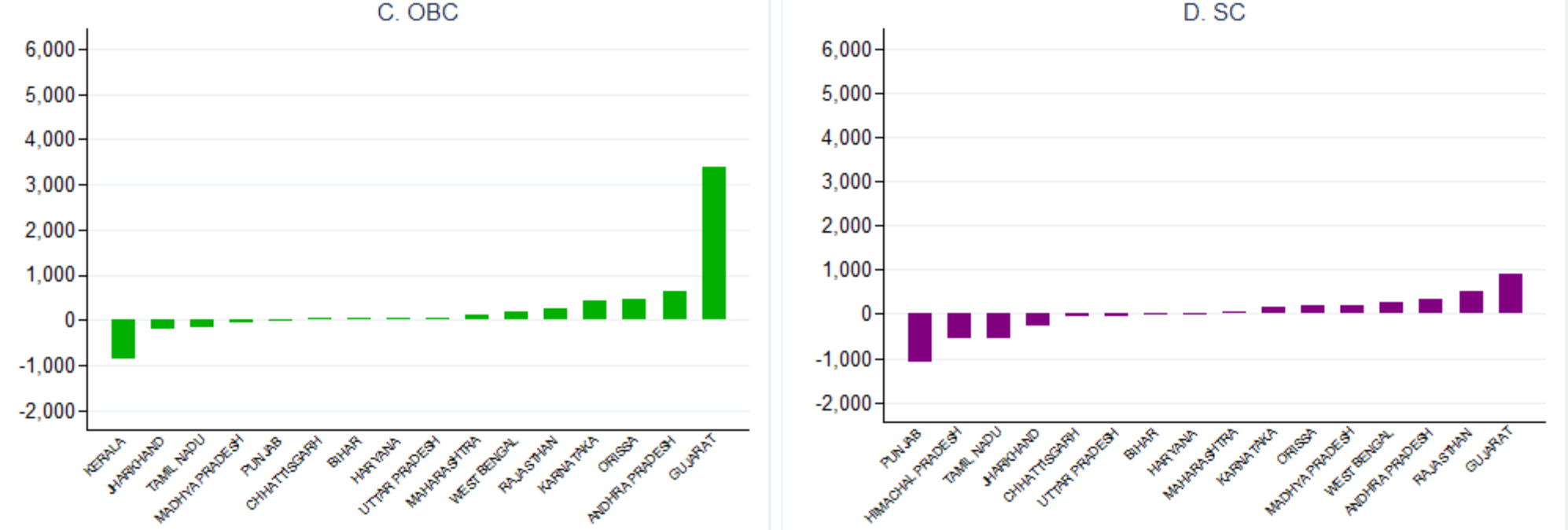

NOTES: This figure shows how average per capita flow of household savings in financial institutions, cash savings, and interest earned during 2007 (in 2005 INR) varies across states within each caste group. OBC and SC stand for other backward classes and scheduled castes, respectively. 
Figure 8: Evidence against sex-selection at first parity

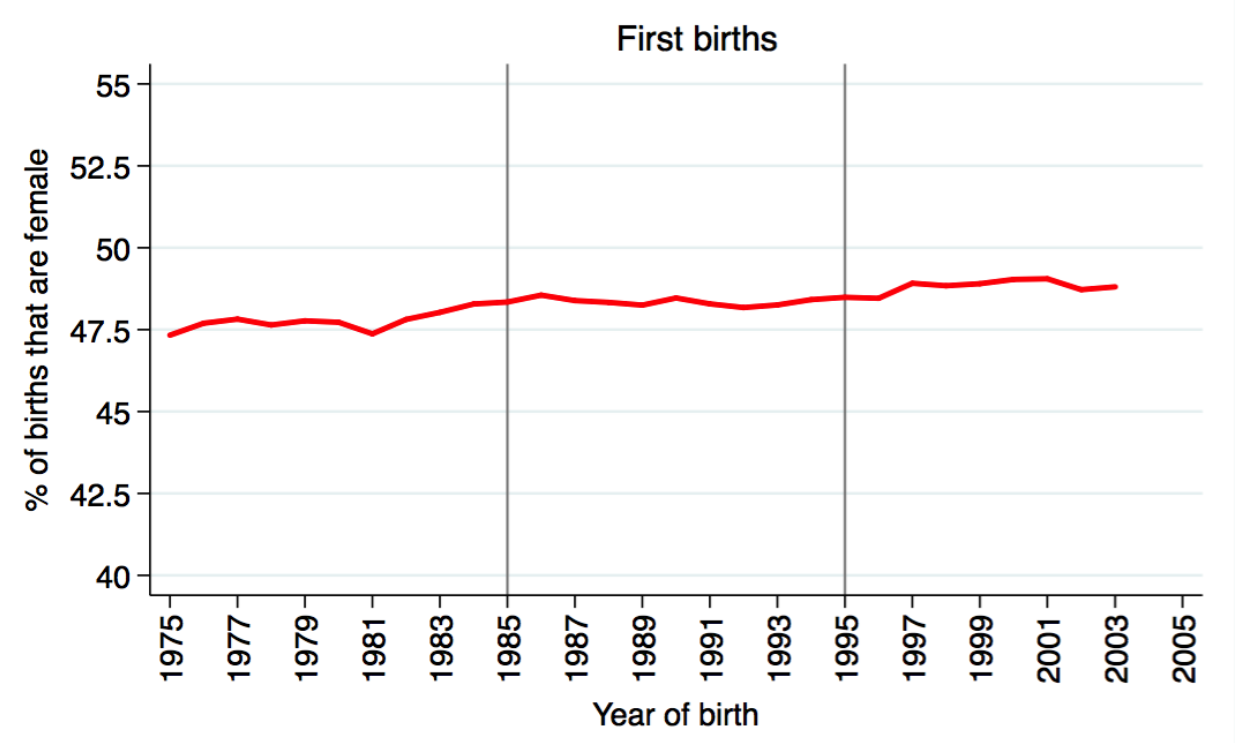

NOTES: This figure shows the evolution of percent female among first births over time using data from the three rounds of the National Family Health Survey of India. The y-axis shows the 5-year moving average of percentage of births that are female. This figure shows that, despite ultrasound availability, the sex ratio of first births has remained normal. The two vertical lines denote the years in which ultrasound availability (a proximate determinant of prenatal sex-selection) underwent structural breaks. Source: Bhalotra and Cochrane (2010). 
Table 1: Average per capita savings

\begin{tabular}{lccc}
\hline & \multicolumn{3}{c}{ Household per capita saving in 2007 (in 2005 INR) } \\
\cline { 2 - 4 } Type of saving: & $\mathrm{N}$ & Mean Flow & Mean Stock \\
\hline Saving in financial institutions & $(1)$ & $(2)$ & $4,306.22$ \\
Saving in financial institutions + Cash & 3,072 & 573.11 & $4,838.41$ \\
Saving in financial institutions + Cash + Interest earned & 3,072 & 477.59 & $5,008.33$ \\
Jewelry & 3,077 & 647.50 & $4,032.46$ \\
Market investments & 2,255 & 125.20 & 964.47 \\
Livestock & 1,768 & -28.75 & $3,406.94$ \\
Durable goods & 3,076 & 262.17 & $4,215.28$ \\
\hline
\end{tabular}

NOTES: This table reports the average value of different types of savings in per capita terms as reported in 2008 for the year before the survey. The flow values in column (2) are constructed as the difference between the value of each item purchased (deposits) and sold (withdrawals) in the reference year. The stock values in column (3) refer to the value of each item at the time of the survey. 
Table 2: Summary statistics

\begin{tabular}{lcccccccl}
\hline & \multicolumn{3}{c}{ All } & \multicolumn{2}{c}{ Firstborn boy } & \multicolumn{2}{c}{ Firstborn girl } & \multirow{2}{*}{ Difference } \\
\cline { 2 - 3 } Household variables: & $\mathrm{N}$ & Mean & $\mathrm{N}$ & Mean & $\mathrm{N}$ & Mean & \\
Expected dowry (in INR 10,000) & 3,078 & 2.612 & 1,738 & 2.597 & 1,340 & 2.632 & -0.035 \\
Father's years of schooling & 2,851 & 6.656 & 1,608 & 6.627 & 1,243 & 6.692 & -0.065 \\
Mother's years of schooling & 3,071 & 3.968 & 1,736 & 3.846 & 1,335 & 4.127 & $-0.281^{*}$ \\
Father's age & 2,855 & 35.614 & 1,612 & 35.635 & 1,243 & 35.587 & 0.048 \\
Mother's age & 3,078 & 31.399 & 1,738 & 31.371 & 1,340 & 31.434 & -0.063 \\
SC & 3,078 & 0.166 & 1,738 & 0.148 & 1,340 & 0.189 & $-0.041^{* * *}$ \\
ST & 3,078 & 0.090 & 1,738 & 0.096 & 1,340 & 0.082 & 0.014 \\
OBC & 3,078 & 0.452 & 1,738 & 0.461 & 1,340 & 0.440 & 0.021 \\
Upper caste & 3,078 & 0.292 & 1,738 & 0.295 & 1,340 & 0.289 & 0.006 \\
Hindu & 3,078 & 0.885 & 1,738 & 0.890 & 1,340 & 0.879 & 0.011 \\
Muslim & 3,078 & 0.063 & 1,738 & 0.059 & 1,340 & 0.068 & -0.009 \\
Sikh & 3,078 & 0.042 & 1,738 & 0.041 & 1,340 & 0.043 & -0.002 \\
BPL & 2,857 & 0.434 & 1,625 & 0.444 & 1,232 & 0.421 & 0.023 \\
Total wealth (PC) & 3,078 & 171,951 & 1,738 & 174,729 & 1,340 & 168,347 & 6,382 \\
\hline
\end{tabular}

NOTES: This table provides means of variables used in the analysis. The sample is restricted to households where all children have the same mother. Firstborn boy (girl) refers to households whose firstborn child is male (female). Expected dowry refers to the average net dowry paid (received) by brides (grooms) from the same caste and state as the child and who married during the year of the child's birth or the prior four years. SC, ST, and OBC denote scheduled castes, scheduled tribes, and other backward classes, respectively. BPL denotes a beneficiary of the Below Poverty Line card. Total wealth (PC) refers to the per capita household wealth in land, assets, livestock, jewelry, durable goods, market investments, savings in financial institutions, and cash in hand. *** $1 \%, * * 5 \%, * 10 \%$. 
Table 3: Dowry expense and the number of daughters

\begin{tabular}{|c|c|c|c|c|c|c|}
\hline \multirow[t]{2}{*}{ Dependent variable: } & \multicolumn{2}{|c|}{ Total dowry paid } & \multicolumn{2}{|c|}{ Dowry paid per married daughter } & \multicolumn{2}{|c|}{$\begin{array}{c}\text { Total dowry paid } \\
\text {-Total dowry received }\end{array}$} \\
\hline & (1) & $(2)$ & $(3)$ & $(4)$ & $(5)$ & (6) \\
\hline No. of married daughters & $\begin{array}{c}29,467.02^{* * *} \\
{[4,858.57]}\end{array}$ & $\begin{array}{c}30,929.49 * * * \\
{[4,567.83]}\end{array}$ & $\begin{array}{l}-1,637.66 \\
{[1,331.35]}\end{array}$ & $\begin{array}{l}-758.47 \\
{[975.88]}\end{array}$ & & \\
\hline Net no. of married daughters & & & & & $\begin{array}{c}12,825.20^{* * *} \\
{[2,288.45]}\end{array}$ & $\begin{array}{r}28,184.69^{* *} \\
{[11,212.55]}\end{array}$ \\
\hline $\mathrm{N}$ & 3,455 & 3,455 & 3,455 & 3,455 & 4,058 & 4,057 \\
\hline Caste FE & & $\mathrm{x}$ & & $\mathrm{x}$ & & $\mathrm{x}$ \\
\hline Religion FE & & $\mathrm{x}$ & & $\mathrm{x}$ & & $\mathrm{x}$ \\
\hline State FE & & $\mathrm{x}$ & & $\mathrm{x}$ & & $\mathrm{x}$ \\
\hline
\end{tabular}

NOTES: In columns (1) and (2), we regress the total net dowry paid by the parents on the number of married daughters. In columns (3) and (4), we regress the net dowry paid per married daughter (defined as the total dowry paid by parents divided by the number of daughters) by the parents on the number of married daughters. In columns (5) and (6), we regress the total net dowry paid by the parents minus the total net dowry received by the parents on the net number of married daughters $(=$ number of married daughters number of married sons). Columns (2), (4), and (6) also control for fixed effects for caste, religion, and state. Standard errors in brackets are clustered by state. ${ }^{* * *} 1 \%, * * 5 \%, * 10 \%$. 
Table 4: Impact of expected dowry on the flow of household per capita saving

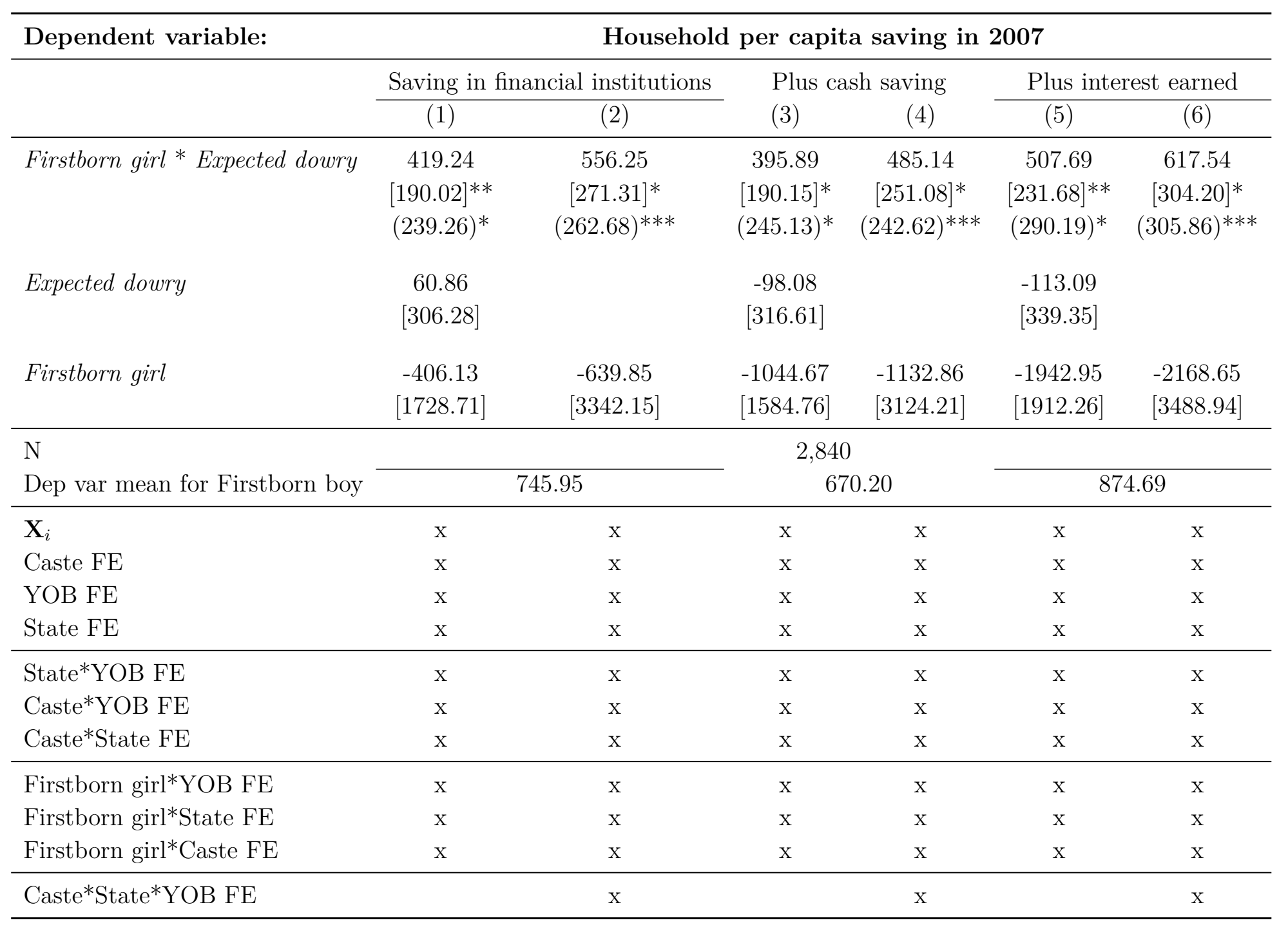

NOTES: This table reports the coefficients from specifications (1) and (2) estimated for households where all children have the same mother. Each column is a separate regression. The dependent variable is the flow of per capita household saving in financial institutions in columns (1) and (2), plus per capita cash saving in columns (3) and (4), and plus per capita interest earning in the last two columns. Firstborn girl indicates that the firstborn child of the household is female. Expected dowry (in INR 10,000) for a female (male) child is defined as the average net dowry paid (received) by brides (grooms) from the same caste and state as the child and who married during the year of the child's birth or the prior four years. Caste refers to indicators for SC, ST, OBC, and upper castes. YOB refers to the year of birth of the firstborn child. State refers to the state of residence at the time of survey. $\mathbf{X}_{i}$ controls for parents' age, schooling, religion, and month of survey. Standard errors in brackets are clustered by state and wild-cluster bootstrapped errors by state are in parentheses. *** $1 \%, * * 5 \%, * 10 \%$. 
Table 5: Robustness checks for the effect on savings

\begin{tabular}{lcc}
\hline Dependent variable: & $\begin{array}{c}\text { Household per capita saving in } \mathbf{2 0 0 7} \\
\text { (financial institutions + cash + interest earned) }\end{array}$ \\
\hline & \multicolumn{2}{c}{ Additional controls: } \\
\cline { 2 - 3 } & $(1)$ & $(2)$ \\
\hline Firstborn girl * Expected dowry & $495.38^{*}$ & $612.76^{*}$ \\
& {$[281.47]$} & {$[211.71]$} \\
Firstborn girl & -512.63 & -2140.94 \\
& {$[3464.00]$} & {$[3522.45]$} \\
\hline $\mathrm{N}$ & 2,840 & 2,840 \\
Dep var mean for Firstborn boy & 874.69 & 874.69 \\
\hline
\end{tabular}

NOTES: This table reports the coefficients for specification (2) controlling for saving deposits at the start of 2008 in column (1) and fixed effects for the number of children in column (2). The sample is restricted to households where all children have the same mother. The dependent variable is the sum total of per capita savings in financial institutions, cash savings, and interest earned in 2007. Each column corresponds to a different regression. Firstborn girl indicates that the firstborn child of the household is female. Expected dowry (in INR 10,000) for a female (male) child is defined as the average net dowry paid (received) by brides (grooms) from the same caste and state as the child and who married during the year of the child's birth or the prior four years. Dep var mean is the mean of the dependent variable for firstborn boy households. Standard errors in brackets are clustered by state. ${ }^{* * *} 1 \%,{ }^{* *} 5 \%,{ }^{*} 10 \%$. 
Table 6: One-child families

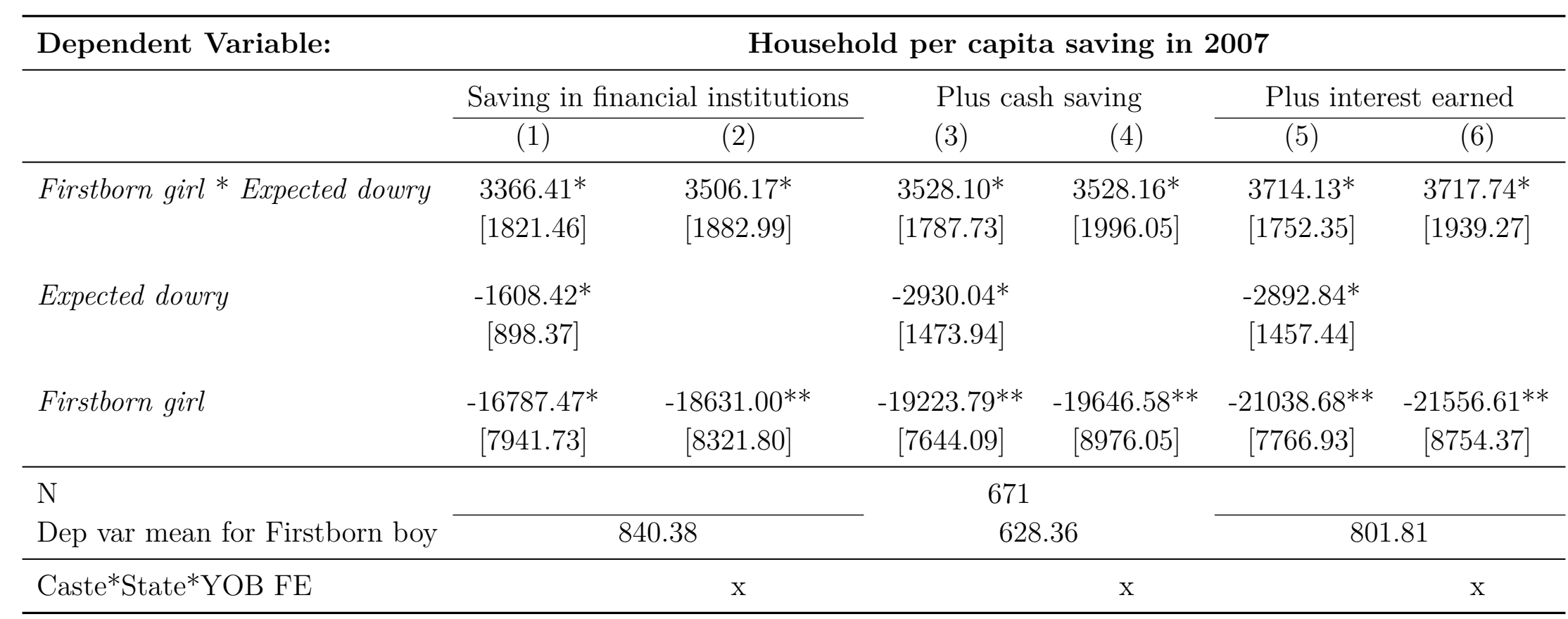

NOTES: This table reports the coefficients corresponding to specifications (1) and (2) estimated for households that have only one child. Each column is a separate regression. The dependent variable is total per capita household saving in financial institutions in columns (1) and (2), plus per capita cash saving in columns (3) and (4), and plus per capita interest earning in the last two columns. Firstborn girl indicates that the firstborn child of the household is female. Expected dowry (in INR 10,000) for a female (male) child is defined as the average net dowry paid (received) by brides (grooms) from the same caste and state as the child and who married during the year of the child's birth or the prior four years. Caste refers to indicators for SC, ST, OBC, and upper castes. YOB refers to the year of birth of the firstborn child. State refers to the state of residence at the time of survey. $\mathbf{X}_{i}$ controls for parents' age, schooling, religion, and month of survey. Standard errors in brackets are clustered by state. *** $1 \%, * * 5 \%, * 10 \%$. 
Table 7: Impact of expected dowry on the flow of other types of savings

\begin{tabular}{lcccc}
\hline Dependent variable: & $\begin{array}{c}\text { Livestock } \\
(1)\end{array}$ & $\begin{array}{c}\text { Market investments } \\
(2)\end{array}$ & $\begin{array}{c}\text { Jewelry } \\
(3)\end{array}$ & $\begin{array}{c}\text { Durable goods } \\
(4)\end{array}$ \\
\hline Firstborn girl * Expected dowry & 331.08 & -93.18 & -5.51 & -67.99 \\
& {$[213.72]$} & {$[60.52]$} & {$[181.92]$} & {$[46.58]$} \\
Firstborn girl & 1533.96 & 391.50 & 147.82 & 401.11 \\
& {$[969.48]$} & {$[559.45]$} & {$[950.41]$} & {$[276.28]$} \\
\hline N & 1,623 & 2,845 & 2,079 & 2,844 \\
Dep var mean for Firstborn boy & -72.32 & 150.11 & 158.26 & 334.76 \\
\hline
\end{tabular}

NOTES: This table reports the coefficients corresponding to specification (2) for different types of saving. The sample is restricted to households where all children have the same mother. Each column is a separate regression. The dependent variables in each column are the flow of per capita household saving in livestock, market investments, jewelry, and durable goods. Firstborn girl indicates that the firstborn child of the household is female. Expected dowry (in INR 10,000) for a female (male) child is defined as the average net dowry paid (received) by brides (grooms) from the same caste and state as the child and who married during the year of the child's birth or the prior four years. Dep var mean is the mean of the dependent variable for firstborn boy households. Standard errors in brackets are clustered by state. $* * * 1 \%, * * 5 \%, * 10 \%$. 
Table 8: Impact of expected dowry on fertility and sex ratio, NFHS data

\begin{tabular}{|c|c|c|c|c|c|}
\hline & (1) & (2) & (3) & (4) & (5) \\
\hline Dependent variable: & \multicolumn{5}{|c|}{ Number of births } \\
\hline Firstborn girl * Expected dowry & & $\begin{array}{c}0.008 \\
{[0.015]}\end{array}$ & $\begin{array}{c}0.002 \\
{[0.013]}\end{array}$ & $\begin{array}{c}0.003 \\
{[0.013]}\end{array}$ & $\begin{array}{c}0.004 \\
{[0.013]}\end{array}$ \\
\hline Firstborn girl & $\begin{array}{c}0.273^{* * *} \\
{[0.032]}\end{array}$ & $\begin{array}{c}0.249^{* * *} \\
{[0.050]}\end{array}$ & $\begin{array}{c}0.290^{* * *} \\
{[0.039]}\end{array}$ & $\begin{array}{c}0.287^{* * *} \\
{[0.041]}\end{array}$ & $\begin{array}{c}0.284^{* * *} \\
{[0.039]}\end{array}$ \\
\hline Expected dowry & & $\begin{array}{l}-0.084 \\
{[0.057]}\end{array}$ & $\begin{array}{l}-0.010 \\
{[0.018]}\end{array}$ & & \\
\hline $\mathrm{N}$ & 60,248 & 60,248 & 60,248 & $60,248759,737$ & \\
\hline Dep var mean for Firstborn boy & 3.095 & 3.095 & 3.095 & 3.095 & 3.095 \\
\hline Dependent variable: & \multicolumn{5}{|c|}{ Fraction sons (parity $\geq 2$ ) } \\
\hline Firstborn girl * Expected dowry & & $\begin{array}{l}0.008^{*} \\
{[0.004]}\end{array}$ & $\begin{array}{c}0.007 \\
{[0.004]}\end{array}$ & $\begin{array}{c}0.007 \\
{[0.004]}\end{array}$ & $\begin{array}{c}0.007 \\
{[0.004]}\end{array}$ \\
\hline Firstborn girl & $\begin{array}{c}0.030 * * * \\
{[0.004]}\end{array}$ & $\begin{array}{c}0.008 \\
{[0.010]}\end{array}$ & $\begin{array}{c}0.009 \\
{[0.010]}\end{array}$ & $\begin{array}{c}0.009 \\
{[0.010]}\end{array}$ & $\begin{array}{c}0.010 \\
{[0.010]}\end{array}$ \\
\hline Expected dowry & & $\begin{array}{c}-0.0002 \\
{[0.002]}\end{array}$ & $\begin{array}{c}-0.008 * * * \\
{[0.003]}\end{array}$ & & \\
\hline $\mathrm{N}$ & 51,243 & 51,243 & 51,243 & 51,243 & 50,810 \\
\hline Dep var mean for Firstborn boy & 0.531 & 0.531 & 0.531 & 0.531 & 0.531 \\
\hline Caste FE + YOB FE + State FE & & & $\mathrm{x}$ & $\mathrm{x}$ & $\mathrm{x}$ \\
\hline State*YOB FE & & & $\mathrm{x}$ & $\mathrm{x}$ & $\mathrm{x}$ \\
\hline Caste $^{*}$ YOB FE & & & $\mathrm{x}$ & $\mathrm{x}$ & $\mathrm{x}$ \\
\hline Caste*State FE & & & $\mathrm{x}$ & $\mathrm{x}$ & $\mathrm{x}$ \\
\hline Caste*State*YOB FE $^{*}$ & & & & $\mathrm{x}$ & $\mathrm{x}$ \\
\hline $\mathbf{X}_{i}$ & & & & & $\mathrm{x}$ \\
\hline
\end{tabular}

NOTES: This table reports the coefficients corresponding to specification (3). Each column is a separate regression. The dependent variable in the top panel is the total number of births and in the bottom panel is the proportion of male births among second and higher parity births. Firstborn girl indicates that the firstborn child of the household is female. Expected dowry (in INR 10,000) for a female (male) child is defined as the average net dowry paid (received) by brides (grooms) from the same caste and state as the child and who married during the year of the child's birth or the prior four years. Dep var mean is the mean of the dependent variable for firstborn-boy households. YOB refers to the year of birth of the firstborn child. $\mathbf{X}_{i}$ controls for parents' age, years of schooling, religion, and household standard of living at the time of survey. Standard errors in brackets are clustered by state. $* * * 1 \%, * * 5 \%, * 10 \%$. 
Table 9: Impact on household per capita saving by poverty status

\begin{tabular}{lcc}
\hline Dependent variable: & \multicolumn{2}{c}{$\begin{array}{c}\text { Household per capita saving in 2007 } \\
\text { (financial institutions }+ \text { cash }+ \text { interest earned) }\end{array}$} \\
\hline & Above poverty line (APL) & Below poverty line (BPL) \\
& $(1)$ & $(2)$ \\
\hline Firstborn girl ${ }^{*}$ Expected dowry & $1881.66^{* *}$ & 71.74 \\
& {$[679.91]$} & {$[114.13]$} \\
Firstborn girl & -5419.96 & -74.37 \\
& {$[5895.24]$} & {$[422.49]$} \\
\hline $\mathrm{N}$ & 1,461 & 1,172 \\
Dep var mean for Firstborn boy & 1415.33 & 135.28 \\
\hline
\end{tabular}

NOTES: This table reports the coefficients for specification (2) separately for APL and BPL households. The BPL status is measured at the time of survey. The sample is restricted to households where all children have the same mother. The dependent variable is the sum total of per capita savings in financial institutions, cash savings, and interest earned in 2007. Each column is a separate regression. Firstborn girl indicates that the first-born child of the household is female. Expected dowry (in INR 10,000) for a female (male) child is defined as the average dowry paid (received) by brides (grooms) from the same caste and state as the child and who married during the year of the child's birth or the prior four years. Dep var mean is the mean of the dependent variable for the firstborn boy households. Standard errors in brackets are clustered by state. *** $1 \%, * * 5 \%, * 10 \%$. 
Table 10: Impact of expected dowry on father's labor supply

\begin{tabular}{lccc}
\hline Dependent Variable: & \multicolumn{3}{c}{ Father's days worked in a year } \\
\hline & All & $\begin{array}{c}\text { Above poverty line } \\
(1)\end{array}$ & $\begin{array}{c}\text { Below poverty line } \\
(2)\end{array}$ \\
\hline Firstborn girl * Post* Expected dowry & $3.64^{* *}$ & $5.54^{* *}$ & 2.19 \\
& {$[1.66]$} & {$[1.95]$} & {$[3.94]$} \\
Expected dowry * Post & 0.89 & -0.24 & -0.66 \\
& {$[2.49]$} & {$[3.17]$} & {$[4.38]$} \\
Firstborn girl * Post & & & -11.32 \\
& $-9.85^{*}$ & $-14.49^{* *}$ & {$[11.77]$} \\
\hline N & {$[5.29]$} & {$[6.77]$} & 29,395 \\
Dep var mean for Firstborn boy & 71,282 & 36,703 & 167.76 \\
\hline
\end{tabular}

NOTES: This table reports the coefficients corresponding to specification (4). The sample is restricted to households where all children have the same mother. Each column corresponds to a different regression. The dependent variable is the number of days worked each year. Firstborn girl indicates that the firstborn child of the household is female. Post indicates that the year of labor is later than the first child's year of birth. Expected dowry (in INR 10,000) for a female (male) child is defined as the average net dowry paid (received) by brides (grooms) from the same caste and state as the child and who married during the year of the child's birth or the prior four years. Dep var mean is the mean of the dependent variable for firstborn boy households. Standard errors in brackets are clustered by state. $* * * 1 \%, * * 5 \%, * 10 \%$. 
Table 11: Impact of expected dowry on borrowing

\begin{tabular}{lcccc}
\hline Dependent Variable: & \multicolumn{5}{c}{ Borrowed last year $=\mathbf{1}$} \\
\hline & $\begin{array}{c}\text { All } \\
(1)\end{array}$ & $\begin{array}{c}\text { All } \\
(2)\end{array}$ & $\begin{array}{c}\text { Above poverty line } \\
(3)\end{array}$ & $\begin{array}{c}\text { Below poverty line } \\
(4)\end{array}$ \\
\hline Firstborn girl * Expected dowry & $0.02^{* *}$ & 0.03 & 0.02 & 0.03 \\
& {$[0.01]$} & {$[0.02]$} & {$[0.04]$} & {$[0.08]$} \\
Expected dowry & 0.04 & & & \\
& {$[0.03]$} & & & -0.21 \\
Firstborn girl & -0.08 & $-0.23^{* *}$ & -0.23 & {$[0.22]$} \\
& {$[0.10]$} & {$[0.09]$} & {$[0.30]$} & 1,176 \\
N & 2,846 & 2,846 & 1,463 & 0.15 \\
Dep var mean for Firstborn boy & 0.19 & 0.19 & 0.24 & $\mathrm{x}$ \\
\hline Caste*State*YOB FE & & $\mathrm{x}$ & $\mathrm{x}$ & \\
\hline
\end{tabular}

NOTES: This table reports the coefficients corresponding to specifications (1) and (2). The sample is restricted to households where all children have the same mother. Each column corresponds to a different regression. The dependent variable is an indicator for borrowing any loan during 2007. Firstborn girl indicates that the firstborn child of the household is female. Expected dowry (in INR 10,000) for a female (male) child is defined as the average net dowry paid (received) by brides (grooms) from the same caste and state as the child and who married during the year of the child's birth or the prior four years. Dep var mean is the mean of the dependent variable for firstborn boy households. Standard errors in brackets are clustered by state. *** $1 \%,{ }^{* *} 5 \%,{ }^{*} 10 \%$. 
Table 12: Impact of expected dowry on child health outcomes by gender using rural NFHS-1,2,3

\begin{tabular}{lcccc}
\hline Dependent variable: & $\begin{array}{c}\text { Wasted } \\
(1)\end{array}$ & $\begin{array}{c}\text { Stunted } \\
(2)\end{array}$ & $\begin{array}{c}\text { Underweight } \\
(3)\end{array}$ & $\begin{array}{c}\text { Low birthweight } \\
(4)\end{array}$ \\
\hline A. Girls & & & & \\
Firstborn girl * Expected dowry & -0.007 & 0.024 & 0.011 & -0.004 \\
& {$[0.009]$} & {$[0.016]$} & {$[0.014]$} & {$[0.012]$} \\
& $1.617^{* * *}$ & $0.801^{* * *}$ & $1.247^{* * *}$ & $1.684^{* *}$ \\
Firstborn girl & {$[0.186]$} & {$[0.199]$} & {$[0.231]$} & {$[0.660]$} \\
& 7,646 & 7,646 & 7,646 & 3,645 \\
\hline B. Boys & & & & -0.003 \\
Firstborn girl * Expected dowry & -0.010 & 0.019 & 0.021 & {$[0.018]$} \\
& {$[0.012]$} & {$[0.015]$} & {$[0.027]$} & $-0.494^{* * *}$ \\
Firstborn girl & $0.319^{* *}$ & $0.437^{* * *}$ & 0.172 & {$[0.085]$} \\
& {$[0.148]$} & {$[0.133]$} & {$[0.151]$} & 4,289 \\
\hline
\end{tabular}

NOTES: This tables reports the coefficients corresponding to specification (5), separately for boys and girls using data from NFHS-1,2,3; the information is collected only for a subset of the women's most recent births. The dependent variables in columns (1)-(4) the outcomes are indicators for the child being wasted, stunted, underweight, and low birthweight based on WHO standards. Firstborn girl indicates that the oldest sibling of the child is female. Expected dowry (in INR 10,000) for the first-born girl (boy) is defined as the average net dowry paid (received) by brides (grooms) from the same caste and state as the child and who married during the year of the child's birth or the prior four years. Standard errors in brackets are clustered by state. ${ }^{* * *} 1 \%,{ }^{* *} 5 \%,{ }^{*} 10 \%$. 
Table 13: Impact of expected dowry on child educational outcomes by gender using rural NFHS-3

\begin{tabular}{|c|c|c|c|c|c|c|}
\hline \multirow[t]{3}{*}{ Dependent variable: } & \multicolumn{6}{|c|}{ Years of schooling } \\
\hline & \multicolumn{2}{|c|}{ All households } & \multicolumn{2}{|c|}{ High \& Medium SLI } & \multicolumn{2}{|c|}{ Low SLI } \\
\hline & $\begin{array}{c}\text { Girls } \\
(1)\end{array}$ & $\begin{array}{c}\text { Boys } \\
(2)\end{array}$ & $\begin{array}{c}\text { Girls } \\
(3)\end{array}$ & $\begin{array}{c}\text { Boys } \\
(4)\end{array}$ & $\begin{array}{l}\text { Girls } \\
(5)\end{array}$ & $\begin{array}{c}\text { Boys } \\
(6)\end{array}$ \\
\hline Firstborn girl * Expected dowry & $\begin{array}{l}-0.014 \\
{[0.023]}\end{array}$ & $\begin{array}{c}-0.054^{* *} \\
{[0.021]}\end{array}$ & $\begin{array}{l}-0.017 \\
{[0.022]}\end{array}$ & $\begin{array}{c}-0.050^{* *} \\
{[0.018]}\end{array}$ & $\begin{array}{l}-0.049 \\
{[0.031]}\end{array}$ & $\begin{array}{l}-0.042 \\
{[0.036]}\end{array}$ \\
\hline Firstborn girl & $\begin{array}{c}0.092 \\
{[0.067]}\end{array}$ & $\begin{array}{l}0.115^{*} \\
{[0.058]}\end{array}$ & $\begin{array}{c}0.096 \\
{[0.083]}\end{array}$ & $\begin{array}{l}0.131^{*} \\
{[0.068]}\end{array}$ & $\begin{array}{c}0.161^{* *} \\
{[0.070]}\end{array}$ & $\begin{array}{c}0.072 \\
{[0.072]}\end{array}$ \\
\hline $\mathrm{N}$ & 17,474 & 19,015 & 70,50 & 7,953 & 10,424 & 11,062 \\
\hline Dep var mean for Firstborn boy & 2.606 & 2.930 & 3.506 & 3.440 & 2.077 & 2.550 \\
\hline
\end{tabular}

NOTES: This tables reports the coefficients corresponding to a specification similar to (2) except for the addition of child age fixed effects here, separately for boys and girls aged 5-15 years using data from NFHS-3. The sample is restricted to children whose mother is alive at the time of the survey. All regressions control for $\mathbf{X}_{i}$ and fixed effects for state, year of first birth, caste, and their double and triple interactions. However, we have to exclude Firstborn girl*YOB FE, Firstborn girl*State FE, and Firstborn girl*Caste FE here because some standard errors are not estimated if all fixed effects are included. Firstborn girl indicates that the oldest sibling of the child is female. Expected dowry (in INR 10,000) for the first-born girl (boy) is defined as the average net dowry paid (received) by brides (grooms) from the same caste and state as the child and who married during the year of the child's birth or the prior four years. High, Medium, and Low SLI refer to the subsamples of households that have respectively high, medium, and low standard of living index in NFHS-3. Standard errors in brackets are clustered by state. ${ }^{* *} 1 \%, * * 5 \%, * 10 \%$. 


\section{A Appendix Figures and Tables}

Figure A.1: Trends in real marriage payments (in INR), by years of schooling
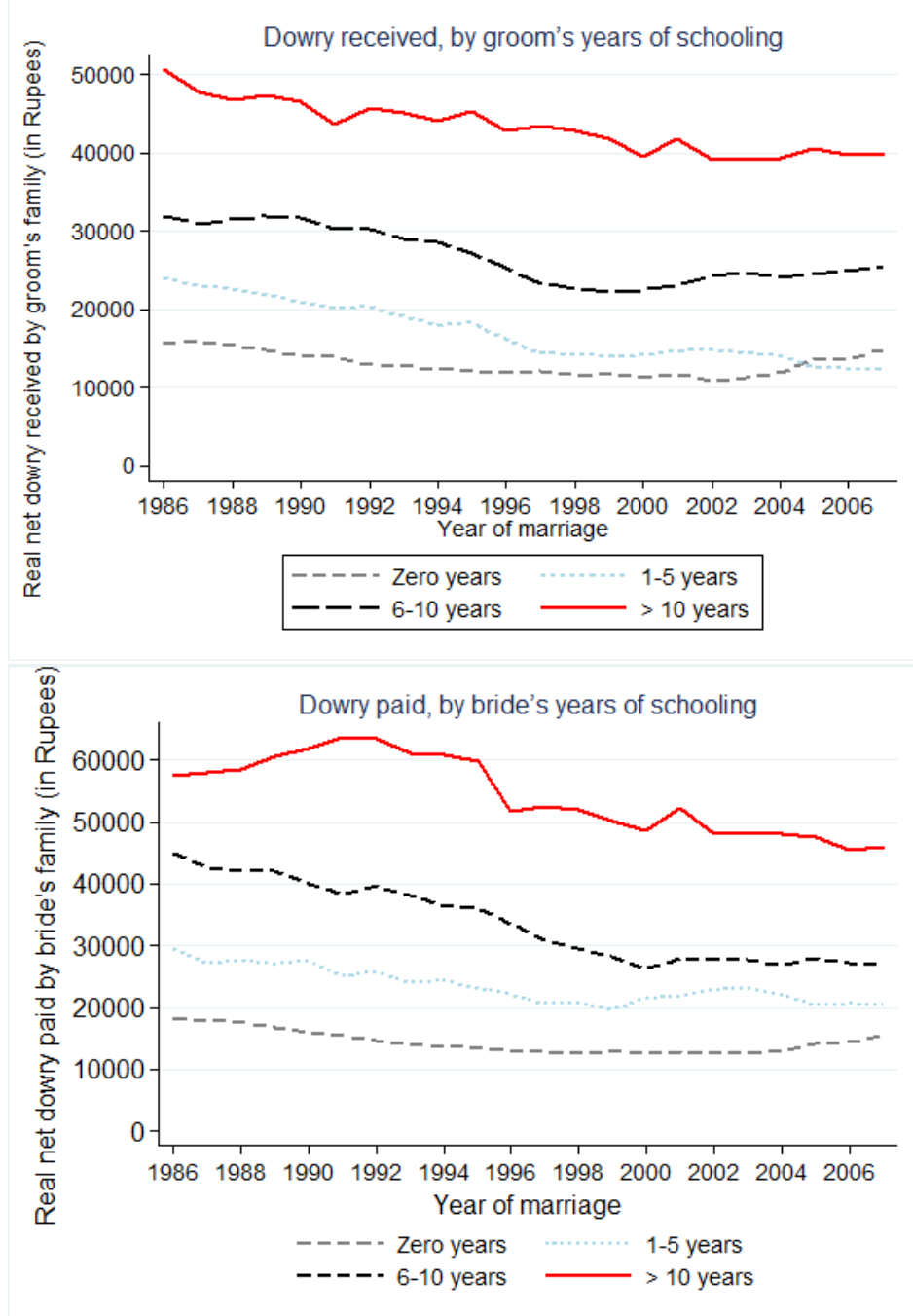

NOTES: This figure plots the 5-year moving unweighted average of real net dowry received by the groom (top graph) and paid by the bride (bottom graph) by year of marriage and years of schooling. 
Figure A.2: Recall bias in real dowry payments (in INR), by year of marriage

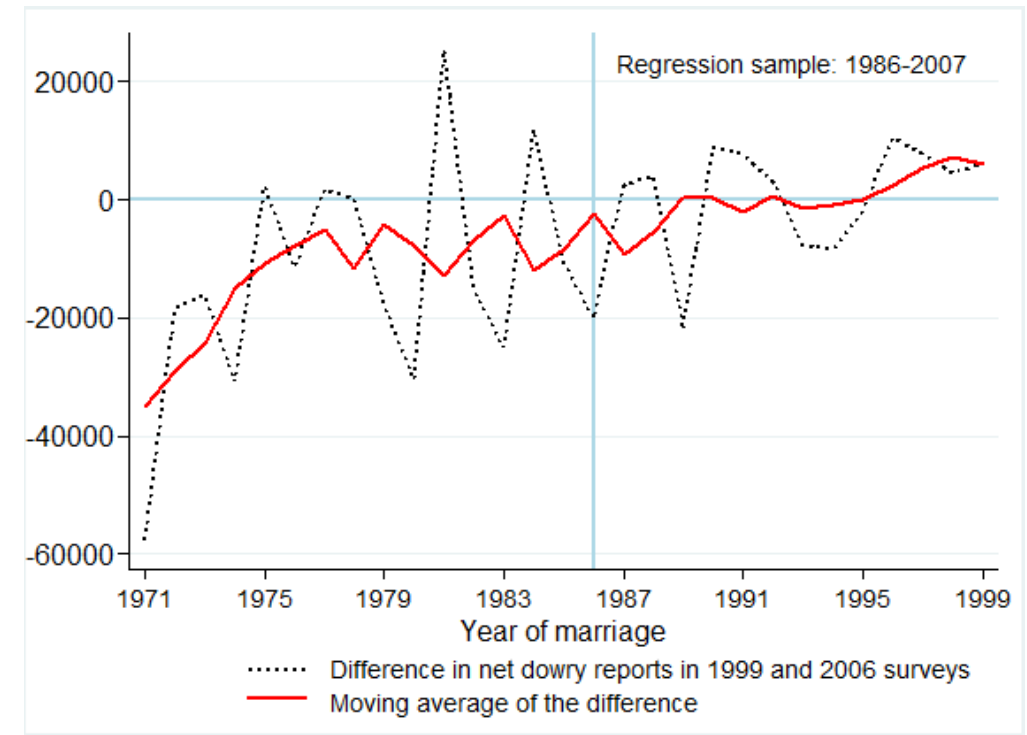

NOTES: The dashed line plots the difference between average real net dowry by year of marriage in the 1999 and 2006 rounds of REDS for marriages that took place during 1986-1999 (2006 minus 1999 amounts). The solid line plots the 5-year moving average of the difference. The vertical line denotes the earliest year included in our regression analysis.

Figure A.3: Assortative matching

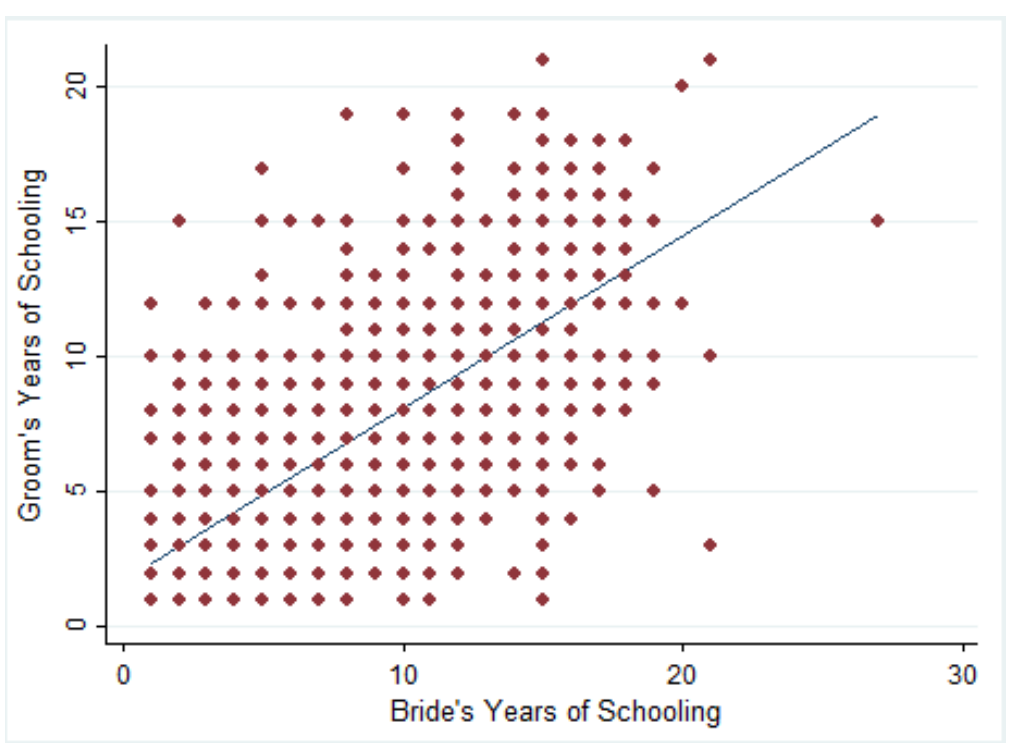

NOTES: This figure shows the relationship between bride's years of schooling and groom's years of schooling. The slope of the linear fitted line is 0.61 and statistically significant at the $1 \%$ level when controlling for caste of the bride and the groom as well as state of residence. The sample includes marriages that took place during 1986-2007; the results remain qualitatively similar if we expand the sample period. 
Table A.1: Does dowry follow a random walk?

\begin{tabular}{rcccc}
\hline Lags & Test Statistic & $1 \%$ Critical Value & $5 \%$ Critical Value & $10 \%$ Critical Value \\
\hline 9 & -0.693 & -3.770 & -2.853 & -2.405 \\
8 & -0.734 & -3.770 & -2.808 & -2.407 \\
7 & -1.260 & -3.770 & -2.820 & -2.453 \\
6 & -0.917 & -3.770 & -2.877 & -2.531 \\
5 & -0.763 & -3.770 & -2.967 & -2.632 \\
4 & -0.964 & -3.770 & -3.078 & -2.747 \\
3 & -0.910 & -3.770 & -3.197 & -2.864 \\
2 & -1.061 & -3.770 & -3.313 & -2.974 \\
1 & -1.644 & -3.770 & -3.414 & -3.067 \\
\hline $\mathrm{N}$ & 23 & & \\
\hline
\end{tabular}

NOTES: This table reports the results from the modified Dickey-Fuller $t$ test (known as the DFGLS test) proposed by Elliott, Rothenberg, and Stock (1996) using STATA's $d f g l s$ command. $d f g l s$ performs the DF-GLS test for the series of models that include 1 to $k$ lags of the first differenced, de trended variable, which is the average real net value of dowry paid during marriages in a given year. We adopt STATA's default approach to picking the optimal $k$. In column (1), we report DF-GLS tau statistic (and its critical values) for the null hypothesis that dowry is a random walk, possibly with drift and the alternate hypothesis that dowry is stationary about a linear time trend. 
Table A.2: Descriptive statistics on wedding expenditure from the 2005 India Human Development Survey

\begin{tabular}{|c|c|c|c|c|c|c|c|c|c|c|}
\hline & \multicolumn{10}{|c|}{ Panel A: By caste } \\
\hline & \multicolumn{5}{|c|}{ Urban } & \multicolumn{5}{|c|}{ Rural } \\
\hline & $\begin{array}{c}\text { Brahmin } \\
\text { (1) }\end{array}$ & $\begin{array}{l}\text { OBC } \\
(2)\end{array}$ & $\begin{array}{l}\mathrm{SC} \\
(3)\end{array}$ & $\begin{array}{l}\mathrm{ST} \\
(4)\end{array}$ & $\begin{array}{c}\text { Others } \\
(5)\end{array}$ & $\begin{array}{c}\text { Brahmin } \\
(6)\end{array}$ & $\begin{array}{c}\mathrm{OBC} \\
(7)\end{array}$ & $\begin{array}{l}\mathrm{SC} \\
(8)\end{array}$ & $\begin{array}{l}\text { ST } \\
(9)\end{array}$ & $\begin{array}{c}\text { Others } \\
(10)\end{array}$ \\
\hline Expenditure by bride's family & 186,683 & 120,818 & 96,038 & 74,689 & 165,710 & 140,575 & 89,973 & 64,194 & 35,007 & 120,038 \\
\hline Expenditure by groom's family & 128,166 & 74,673 & 63,616 & 58,691 & 108,188 & 92,365 & 56,380 & 43,539 & 29,176 & 74,162 \\
\hline Difference & 58,617 & 46,145 & 32,423 & 15,997 & 57,522 & 48,210 & 33,589 & 20,655 & 5,835 & 45,875 \\
\hline $\mathrm{N}$ & 1,313 & 5,452 & 2,322 & 499 & 4,956 & 1,108 & 10,834 & 6,011 & 2,939 & 6,118 \\
\hline \multicolumn{11}{|c|}{ Panel B: By religion } \\
\hline & \multicolumn{4}{|c|}{ Urban } & \multicolumn{4}{|c|}{ Rural } & & \\
\hline & $\begin{array}{l}\text { Hindu } \\
(1)\end{array}$ & $\begin{array}{c}\text { Muslim } \\
(2)\end{array}$ & $\begin{array}{c}\text { Christian } \\
(3) \\
\end{array}$ & $\begin{array}{c}\text { Sikh } \\
(4)\end{array}$ & $\begin{array}{c}\text { Hindu } \\
(5)\end{array}$ & $\begin{array}{c}\text { Muslim } \\
(6)\end{array}$ & $\begin{array}{c}\text { Christian } \\
(7)\end{array}$ & $\begin{array}{c}\text { Sikh } \\
(8)\end{array}$ & & \\
\hline Expenditure by bride's family & 137,992 & 119,959 & 143,553 & 194,341 & 84,014 & 100,849 & 103,211 & 161,513 & & \\
\hline Expenditure by groom's family & 90,649 & 76,515 & 66,274 & 132,988 & 55,309 & 57,894 & 48,767 & 107,471 & & \\
\hline Difference & 47,350 & 43,444 & 77,278 & 61,353 & 28,706 & 42,956 & 54,443 & 54,042 & & \\
\hline $\mathrm{N}$ & 11,286 & 2,215 & 514 & 258 & 22,239 & 2,573 & 862 & 732 & & \\
\hline
\end{tabular}

NOTES: This table provides means of wedding expenditure in the 2005 India Human Development Survey (IHDS). The survey asks "At the time of the marriage in your community (jati) for a family like yours, how much money is usually spent by the girl(boy)'s family?" The IHDS data set has five broad social groups: (1) Brahmin (2) OBC (3) SC (4) ST (5) Others. 
Table A.3: Composition of dowries in rural India, 2005 IHDS

\begin{tabular}{rc}
\hline Item & \% of households that respond "Usually given" \\
\hline Utensils & 80.42 \\
Bedding/mattress & 70.94 \\
Gold & 70.78 \\
Silver & 63.85 \\
Watch & 62.41 \\
Furniture & 48.89 \\
Cash & 41.03 \\
Pressure cooker & 35.12 \\
Sewing machine & 21.71 \\
TV & 20.42 \\
Bicycle & 16.60 \\
Mixer or grinder & 15.70 \\
Fridge & 9.81 \\
Livestock & 8.78 \\
Land & 7.49 \\
Car & 1.04 \\
Tractor & 0.44 \\
Scooter or motorcycle & 0.32 \\
\hline
\end{tabular}

NOTES: This table shows the percentage of rural households that respond "Usually" to the following question: Generally in your community for a family like yours, what are the kind of things that are given as gifts at the time of the daughter's marriage? in 2005 IHDS. 
Table A.4: Total (instead of per capita) household saving

\begin{tabular}{|c|c|c|c|c|c|c|}
\hline \multirow[t]{3}{*}{ Dependent variable: } & \multicolumn{6}{|c|}{ Total Household Saving in 2007} \\
\hline & \multicolumn{2}{|c|}{ Saving in financial institutions } & \multicolumn{2}{|c|}{ Plus cash saving } & \multicolumn{2}{|c|}{ Plus interest earned } \\
\hline & $(1)$ & $(2)$ & $(3)$ & $(4)$ & $(5)$ & (6) \\
\hline \multirow[t]{2}{*}{ Firstborn girl * Expected dowry } & $2,527.05^{* *}$ & $3,069.96^{*}$ & $2,457.32^{* *}$ & $2,895.15^{* *}$ & $3,176.43^{* *}$ & $3,789.41^{*}$ \\
\hline & {$[933.70]$} & {$[1,460.11]$} & {$[929.53]$} & {$[1,288.65]$} & {$[1,318.99]$} & {$[1,877.15]$} \\
\hline \multirow[t]{2}{*}{ Expected dowry } & 450.71 & & -224.83 & & -436.14 & \\
\hline & {$[1,678.00]$} & & {$[1,650.52]$} & & {$[1,841.82]$} & \\
\hline \multirow[t]{2}{*}{ Firstborn girl } & $-3,798.81$ & $-5,508.50$ & $-7,405.35$ & $-9,032.55$ & $-12,743.13$ & $-15,613.02$ \\
\hline & {$[9,699.30]$} & {$[17,428.85]$} & {$[8,999.26]$} & {$[16,102.43]$} & {$[11,315.43]$} & {$[19,124.74]$} \\
\hline $\mathrm{N}$ & \multicolumn{6}{|c|}{2,840} \\
\hline $\mathbf{X}_{i}$ & $\mathrm{x}$ & $\mathrm{x}$ & $\mathrm{x}$ & $\mathrm{x}$ & $\mathrm{x}$ & $\mathrm{x}$ \\
\hline Caste FE & $\mathrm{x}$ & $\mathrm{x}$ & $\mathrm{x}$ & $\mathrm{x}$ & $\mathrm{x}$ & $\mathrm{x}$ \\
\hline YOB FE & $\mathrm{x}$ & $\mathrm{x}$ & $\mathrm{x}$ & $\mathrm{x}$ & $\mathrm{x}$ & $\mathrm{x}$ \\
\hline State FE & $\mathrm{x}$ & $\mathrm{x}$ & $\mathrm{x}$ & $\mathrm{x}$ & $\mathrm{x}$ & $\mathrm{x}$ \\
\hline State*YOB FE $^{*}$ & $\mathrm{x}$ & $\mathrm{x}$ & $\mathrm{x}$ & $\mathrm{x}$ & $\mathrm{x}$ & $\mathrm{x}$ \\
\hline Caste*YOB FE & $\mathrm{x}$ & $\mathrm{x}$ & $\mathrm{x}$ & $\mathrm{x}$ & $\mathrm{x}$ & $\mathrm{x}$ \\
\hline Caste*State FE & $\mathrm{x}$ & $\mathrm{x}$ & $\mathrm{x}$ & $\mathrm{x}$ & $\mathrm{x}$ & $\mathrm{x}$ \\
\hline Firstborn girl*YOB FE & $\mathrm{x}$ & $\mathrm{x}$ & $\mathrm{x}$ & $\mathrm{x}$ & $\mathrm{x}$ & $\mathrm{x}$ \\
\hline Firstborn girl*State FE & $\mathrm{x}$ & $\mathrm{x}$ & $\mathrm{x}$ & $\mathrm{x}$ & $\mathrm{x}$ & $\mathrm{x}$ \\
\hline Firstborn girl*Caste FE & $\mathrm{x}$ & $\mathrm{x}$ & $\mathrm{x}$ & $\mathrm{x}$ & $\mathrm{x}$ & $\mathrm{x}$ \\
\hline Caste*State*YOB FE $^{*}$ & & $\mathrm{x}$ & & $\mathrm{x}$ & & $\mathrm{x}$ \\
\hline
\end{tabular}

NOTES: This table reports the coefficients corresponding to specifications (1) and (2) estimated for households where all children have the same mother. Each column is a separate regression. The dependent variable is total household saving in financial institutions in columns (1) and (2), plus cash saving in columns (3) and (4), and plus interest earning in the last two columns. Firstborn girl indicates that the firstborn child of the household is female. Expected dowry (in INR 10,000) for a female (male) child is defined as the average net dowry paid (received) by brides (grooms) from the same caste and state as the child and who married during the year of the child's birth or the prior four years. Caste refers to indicators for SC, ST, OBC, and upper castes. YOB refers to the year of birth of the firstborn child. State refers to the state of residence at the time of survey. $\mathbf{X}_{i}$ controls for parents' age, schooling, religion, and month of survey. Standard errors in brackets are clustered by state. *** $1 \%, * * 5 \%, * 10 \%$. 
Table A.5: Stock of per capita household saving

\begin{tabular}{lcccc}
\hline Dependent variable: & \multicolumn{4}{c}{ Per capita stock of saving in 2007 } \\
\cline { 2 - 5 } & Livestock & Market investments & Jewelry & Durable goods \\
& $(1)$ & $(2)$ & $(3)$ & $(4)$ \\
\hline A: Below poverty line & & & & \\
Firstborn girl * Expected dowry & 315.99 & -558.80 & -883.42 & 178.84 \\
& {$[583.19]$} & {$[1,157.03]$} & {$[864.38]$} & {$[407.08]$} \\
$\mathrm{N}$ & 546 & 833 & 1,176 & 1,175 \\
\hline B: Above poverty line & \multicolumn{3}{c}{} \\
Firstborn girl * Expected dowry & -717.60 & $-2,267.07$ & $-1,088.76$ & -265.10 \\
& {$[1,411.16]$} & {$[1,584.68]$} & {$[969.70]$} & {$[1,794.44]$} \\
$\mathrm{N}$ & 962 & 1,102 & 1,463 & 1,462 \\
\hline
\end{tabular}

NOTES: This table reports the coefficients corresponding to specification (2) for different types of saving. The sample is restricted to households where all children have the same mother. Each column is a separate regression. The dependent variables in each column are the flow of per capita household saving in livestock, market investments, jewelry, and durable goods. Firstborn girl indicates that the firstborn child of the household is female. Expected dowry (in INR 10,000) for a female (male) child is defined as the average net dowry paid (received) by brides (grooms) from the same caste and state as the child and who married during the year of the child's birth or the prior four years. Panel A uses the sample of below poverty line families, while panel B examines above poverty line households. Standard errors in brackets are clustered by state. *** $1 \%, * * 5 \%, * 10 \%$. 
Table A.6: Impact of expected dowry on fertility and sex ratio, REDS data

\begin{tabular}{|c|c|c|c|c|c|}
\hline & (1) & $(2)$ & (3) & (4) & (5) \\
\hline Dependent variable: & \multicolumn{5}{|c|}{ Number of births } \\
\hline Firstborn girl * Expected dowry & & $\begin{array}{c}0.085^{* *} \\
{[0.031]}\end{array}$ & $\begin{array}{l}0.054^{*} \\
{[0.029]}\end{array}$ & $\begin{array}{c}0.055 \\
{[0.042]}\end{array}$ & $\begin{array}{c}0.044 \\
{[0.045]}\end{array}$ \\
\hline Firstborn girl & $\begin{array}{c}0.302^{* * *} \\
{[0.060]}\end{array}$ & $\begin{array}{c}0.080 \\
{[0.126]}\end{array}$ & $\begin{array}{c}0.123 \\
{[0.124]}\end{array}$ & $\begin{array}{c}0.119 \\
{[0.161]}\end{array}$ & $\begin{array}{c}0.132 \\
{[0.156]}\end{array}$ \\
\hline Expected dowry & & $\begin{array}{l}-0.060 \\
{[0.041]}\end{array}$ & $\begin{array}{l}-0.022 \\
{[0.074]}\end{array}$ & & \\
\hline $\begin{array}{l}\text { N } \\
\text { Dep var mean for Firstborn bov }\end{array}$ & $\begin{array}{l}3,078 \\
2285\end{array}$ & $\begin{array}{l}3,078 \\
2285\end{array}$ & $\begin{array}{l}3,078 \\
2285\end{array}$ & $\begin{array}{l}3,078 \\
2285\end{array}$ & $\begin{array}{l}2,846 \\
2,285\end{array}$ \\
\hline Dependent variable: & \multicolumn{5}{|c|}{ Fraction sons (parity $\geq 2$ ) } \\
\hline Firstborn girl * Expected dowry & & $\begin{array}{l}-0.004 \\
{[0.010]}\end{array}$ & $\begin{array}{l}-0.007 \\
{[0.015]}\end{array}$ & $\begin{array}{l}-0.008 \\
{[0.019]}\end{array}$ & $\begin{array}{l}-0.011 \\
{[0.024]}\end{array}$ \\
\hline Firstborn girl & $\begin{array}{c}0.073^{* * *} \\
{[0.021]}\end{array}$ & $\begin{array}{c}0.084^{*} \\
[0.043])\end{array}$ & $\begin{array}{c}0.101 \\
{[0.059]}\end{array}$ & $\begin{array}{c}0.102 \\
{[0.073]}\end{array}$ & $\begin{array}{c}0.113 \\
{[0.079]}\end{array}$ \\
\hline Expected dowry & & $\begin{array}{c}0.009 \\
{[0.007]}\end{array}$ & $\begin{array}{l}-0.002 \\
{[0.029]}\end{array}$ & & \\
\hline $\mathrm{N}$ & 2,342 & 2,342 & 2,342 & 2,342 & 2,174 \\
\hline Dep var mean for Firstborn boy & 0.535 & 0.535 & 0.535 & 0.535 & 0.535 \\
\hline Caste FE + YOB FE + State FE & & & $\mathrm{x}$ & $\mathrm{x}$ & $\mathrm{x}$ \\
\hline State*YOB FE & & & $\mathrm{x}$ & $\mathrm{x}$ & $\mathrm{x}$ \\
\hline Caste*YOB FE & & & $\mathrm{x}$ & $\mathrm{x}$ & $\mathrm{x}$ \\
\hline Caste*State FE & & & $\mathrm{x}$ & $\mathrm{x}$ & $\mathrm{x}$ \\
\hline Caste*State*YOB FE & & & & $\mathrm{x}$ & $\mathrm{x}$ \\
\hline $\mathbf{X}_{i}$ & & & & & $\mathrm{x}$ \\
\hline
\end{tabular}

NOTES: This table reports the coefficients corresponding to specification (3). Each column is a separate regression. The sample is restricted to households where all children have the same mother. The dependent variable is the proportion of male births among second and higher parity births. Firstborn girl indicates that the firstborn child of the household is female. Expected dowry (in INR 10,000) for a female (male) child is defined as the average net dowry paid (received) by brides (grooms) from the same caste and state as the child and who married during the year of the child's birth or the prior four years. Dep var mean is the mean of the dependent variable for firstborn-boy households. YOB refers to the year of birth of the firstborn child. Standard errors in brackets are clustered by state. *** $1 \%, * * 5 \%, * 10 \%$. 
Table A.7: Consumption

\begin{tabular}{|c|c|c|c|c|c|c|}
\hline & \multicolumn{2}{|c|}{ PC total expenditure } & \multicolumn{2}{|c|}{ PC food expenditure } & \multicolumn{2}{|c|}{ PC non-food expenditure } \\
\hline & $\begin{array}{l}\text { APL } \\
(1)\end{array}$ & $\begin{array}{c}\text { BPL } \\
(2)\end{array}$ & $\begin{array}{c}\text { APL } \\
(3)\end{array}$ & $\begin{array}{c}\mathrm{BPL} \\
(4)\end{array}$ & $\begin{array}{c}\mathrm{APL} \\
(5)\end{array}$ & $\begin{array}{c}\mathrm{BPL} \\
(6)\end{array}$ \\
\hline Firstborn girl & $\begin{array}{c}-7,402.23^{*} \\
{[3,786.08]}\end{array}$ & $\begin{array}{c}1,367.72 \\
{[1,092.65]}\end{array}$ & $\begin{array}{c}-3,017.97^{* * *} \\
{[792.89]}\end{array}$ & $\begin{array}{c}-1,036.98^{* * *} \\
{[326.73]}\end{array}$ & $\begin{array}{l}-2,465.83 \\
{[3,853.80]}\end{array}$ & $\begin{array}{c}-1,457.76^{*} \\
{[809.42]}\end{array}$ \\
\hline $\mathrm{N}$ & 1,463 & 1,176 & 1,451 & 1,162 & 1,451 & 1,162 \\
\hline
\end{tabular}

NOTES: This table reports the coefficients corresponding to specification (2) estimated for households where all children have the same mother, separately for above poverty line (APL) and below poverty line (BPL) families. Each column is a separate regression. The dependent variable is total per capita consumption expenditure in columns (1) and (2), per capita food expenditure in columns (3) and (4), and per capita non-food expenditure in columns (5) and (6). Firstborn girl indicates that the firstborn child of the household is female. Expected dowry (in INR 10,000) for a female (male) child is defined as the average net dowry paid (received) by brides (grooms) from the same caste and state as the child and who married during the year of the child's birth or the prior four years. Standard errors in brackets are clustered by state. ${ }^{* * *} 1 \%,{ }^{*} * 5 \%, * 10 \%$. 
Table A.8: Flow of Household per capita saving, by religion

\begin{tabular}{|c|c|c|c|c|c|c|}
\hline \multirow[t]{3}{*}{ Dependent variable: } & \multicolumn{6}{|c|}{ Household per capita saving in 2007} \\
\hline & \multicolumn{3}{|c|}{ Hindus } & \multicolumn{3}{|c|}{ Non-Hindus } \\
\hline & $\begin{array}{c}\text { Saving in } \\
\text { financial institutions } \\
(1)\end{array}$ & $\begin{array}{l}+ \text { cash } \\
\text { saving } \\
(2)\end{array}$ & $\begin{array}{c}+ \text { interest } \\
\text { earned } \\
(3)\end{array}$ & $\begin{array}{c}\text { Saving in } \\
\text { financial institutions } \\
(4)\end{array}$ & $\begin{array}{c}+ \text { cash } \\
\text { saving } \\
(5)\end{array}$ & $\begin{array}{c}\text { + interest } \\
\text { earned } \\
(6)\end{array}$ \\
\hline Firstborn girl ${ }^{*}$ Expected dowry & $\begin{array}{c}799.93^{* *} \\
{[366.70]}\end{array}$ & $\begin{array}{l}683.25^{*} \\
{[343.17]}\end{array}$ & $\begin{array}{l}889.28^{*} \\
{[447.13]}\end{array}$ & $\begin{array}{c}145.25 \\
{[841.86]}\end{array}$ & $\begin{array}{c}236.60 \\
{[837.35]}\end{array}$ & $\begin{array}{c}-17.20 \\
{[961.95]}\end{array}$ \\
\hline Firstborn girl & $\begin{array}{l}-2,492.21 \\
{[2,992.07]}\end{array}$ & $\begin{array}{l}-2,847.52 \\
{[2,761.29]}\end{array}$ & $\begin{array}{l}-4,363.68 \\
{[3,278.80]}\end{array}$ & $\begin{array}{c}2,874.54 \\
{[5,678.14]}\end{array}$ & $\begin{array}{c}919.26 \\
{[5,527.69]}\end{array}$ & $\begin{array}{c}398.76 \\
{[6,368.59]}\end{array}$ \\
\hline $\mathrm{N}$ & \multicolumn{3}{|c|}{2,521} & \multicolumn{3}{|c|}{319} \\
\hline
\end{tabular}

NOTES: This table reports the coefficients corresponding to specification (2) estimated for households where all children have the same mother, separately for Hindus and non-Hindus. Each column is a separate regression. The dependent variable is total per capita household saving in financial institutions in columns (1) and (4), plus per capita cash saving in columns (2) and (5), and plus per capita interest earning in columns (3) and (6). Firstborn girl indicates that the firstborn child of the household is female. Expected dowry (in INR $10,000)$ for a female (male) child is defined as the average net dowry paid (received) by brides (grooms) from the same caste and state as the child and who married during the year of the child's birth or the prior four years. Standard errors in brackets are clustered by state. *** $1 \%, * * 5 \%, * 10 \%$. 
Table A.9: Correlation between couple's education and dowry

\begin{tabular}{lccc}
\hline Dependent variables: & $\begin{array}{c}\text { Net dowry } \\
(1)\end{array}$ & $\begin{array}{c}\text { Gross payments by bride } \\
(2)\end{array}$ & $\begin{array}{c}\text { Gross payments by groom } \\
(3)\end{array}$ \\
\hline Bride's years of schooling & $1,551.64^{* *}$ & $2,045.11^{*}$ & 102.74 \\
& {$[654.38]$} & {$[1,002.06]$} & {$[165.08]$} \\
Groom's years of schooling & $2,302.61^{* * *}$ & $2,595.90^{* * *}$ & 280.22 \\
& {$[668.89]$} & {$[730.37]$} & {$[194.78]$} \\
Bride's age at marriage & -54.58 & 90.31 & -94.23 \\
& {$[973.54]$} & {$[940.46]$} & {$[232.66]$} \\
\hline $\mathrm{N}$ & 1,712 & 1,712 & 1,715 \\
\hline
\end{tabular}

NOTES: This table examines how net dowry and gross payments by the bride and the groom vary with the bride's and the groom' years of schooling. We control for bride's age at marriage and include fixed effects for state, bride's caste, groom's caste, and bride's religion in all columns. We drop a few outliers with years of schooling $>30$. The sample includes marriages that took place during 1986-2007; the results remain qualitatively similar if we expand the sample period. *** $1 \%$, $* * 5 \%, * 10 \%$. 
Table A.10: Robustness

\begin{tabular}{|c|c|c|c|}
\hline \multirow[t]{2}{*}{ Dependent variable: } & \multicolumn{3}{|c|}{$\begin{array}{c}\text { Household per capita saving in } 2007 \\
\text { (financial institutions }+ \text { cash }+ \text { interest earned) }\end{array}$} \\
\hline & $\begin{array}{l}\text { Caste-religion } \\
\text { (1) }\end{array}$ & $\begin{array}{l}\text { Around YOB } \\
(2)\end{array}$ & $\begin{array}{l}\text { Non-missing obs. } \\
\text { (3) }\end{array}$ \\
\hline Firstborn girl $*$ Expected dowry & $\begin{array}{c}623.55^{* *} \\
{[220.87]}\end{array}$ & $\begin{array}{l}368.73^{*} \\
{[200.02]}\end{array}$ & $\begin{array}{l}637.40^{*} \\
{[354.23]}\end{array}$ \\
\hline Firstborn girl & $\begin{array}{l}-3228.32 \\
{[2032.56]}\end{array}$ & $\begin{array}{l}-826.20 \\
{[2359.00]}\end{array}$ & $\begin{array}{c}-3635.87^{* *} \\
{[1669.78]}\end{array}$ \\
\hline $\mathrm{N}$ & 2,836 & 2,837 & 2,610 \\
\hline
\end{tabular}

NOTES: This table reports the coefficients corresponding to specification (2) estimated for households where all children have the same mother. Each column is a separate regression. The dependent variable is the sum total of per capita savings in financial institutions, cash savings, and interest earned in 2007. Firstborn girl indicates that the firstborn child of the household is female. Expected dowry (in INR 10,000) for a female (male) child is defined as the average dowry paid (received) by brides (grooms) from the same social group and state as the child and who married during the year of the child's birth or the prior four years. In column (1), we construct seven social groups based on the caste and religion. Specifically, we split Hindus by caste and use other religions as it is (i.e., Hindu SCs, Hindu STs, Hindu OBCs, Hindu OCs, Muslims, Sikhs, Other religions). In column (2), expected dowry is defined using marriages around the year of birth (YOB) of the child (i.e., during $\mathrm{YOB}+2$, YOB +1 , YOB, YOB - 1, YOB - 2). In column (3), we construct expected dowry only using marriages where both gifts are non-missing. Standard errors in brackets are clustered by state. $* * * 1 \%, * * 5 \%, * 10 \%$. 
Table A.11: Savings: Using median dowry to proxy for expected dowry

\begin{tabular}{|c|c|c|c|c|c|c|}
\hline \multirow[t]{3}{*}{ Dependent variable: } & \multicolumn{6}{|c|}{ Per Capita Household Saving in 2007} \\
\hline & \multicolumn{2}{|c|}{ Saving in financial institutions } & \multicolumn{2}{|c|}{ Plus cash saving } & \multicolumn{2}{|c|}{ Plus interest earned } \\
\hline & (1) & $(2)$ & $(3)$ & $(4)$ & $(5)$ & (6) \\
\hline Firstborn girl $*$ Expected dowry & $\begin{array}{c}507.76^{* *} \\
{[174.49]}\end{array}$ & $\begin{array}{c}524.60^{* *} \\
{[240.32]}\end{array}$ & $\begin{array}{c}500.14^{* *} \\
{[188.95]}\end{array}$ & $\begin{array}{l}488.13^{*} \\
{[264.50]}\end{array}$ & $\begin{array}{c}627.44^{* *} \\
{[266.96]}\end{array}$ & $\begin{array}{c}648.63 \\
{[393.25]}\end{array}$ \\
\hline Expected dowry & $\begin{array}{c}42.75 \\
{[217.73]}\end{array}$ & & $\begin{array}{l}-229.43 \\
{[258.55]}\end{array}$ & & $\begin{array}{l}-218.03 \\
{[271.38]}\end{array}$ & \\
\hline Firstborn girl & $\begin{array}{c}-152.45 \\
{[1,500.31]}\end{array}$ & $\begin{array}{c}270.08 \\
{[2,914.30]}\end{array}$ & $\begin{array}{c}-869.37 \\
{[1,520.13]}\end{array}$ & $\begin{array}{c}-460.25 \\
{[2,909.32]}\end{array}$ & $\begin{array}{l}-1,666.66 \\
{[1,836.77]}\end{array}$ & $\begin{array}{l}-1,420.38 \\
{[3,376.16]}\end{array}$ \\
\hline $\mathrm{N}$ & & & 2,840 & & & \\
\hline $\mathbf{X}_{i}$ & $\mathrm{x}$ & $\mathrm{x}$ & $\mathrm{x}$ & $\mathrm{x}$ & $\mathrm{x}$ & $\mathrm{x}$ \\
\hline Caste FE & $\mathrm{x}$ & $\mathrm{x}$ & $\mathrm{x}$ & $\mathrm{x}$ & $\mathrm{x}$ & $\mathrm{x}$ \\
\hline YOB FE & $\mathrm{x}$ & $\mathrm{x}$ & $\mathrm{x}$ & $\mathrm{x}$ & $\mathrm{x}$ & $\mathrm{x}$ \\
\hline State FE & $\mathrm{x}$ & $\mathrm{x}$ & $\mathrm{x}$ & $\mathrm{x}$ & $\mathrm{x}$ & $\mathrm{x}$ \\
\hline State*YOB FE & $\mathrm{x}$ & $\mathrm{x}$ & $\mathrm{x}$ & $\mathrm{x}$ & $\mathrm{x}$ & $\mathrm{x}$ \\
\hline Caste*YOB FE $^{*}$ & $\mathrm{x}$ & $\mathrm{x}$ & $\mathrm{x}$ & $\mathrm{x}$ & $\mathrm{x}$ & $\mathrm{x}$ \\
\hline Caste*State FE & $\mathrm{x}$ & $\mathrm{x}$ & $\mathrm{x}$ & $\mathrm{x}$ & $\mathrm{x}$ & $\mathrm{x}$ \\
\hline Firstborn girl*YOB FE & $\mathrm{x}$ & $\mathrm{x}$ & $\mathrm{x}$ & $\mathrm{x}$ & $\mathrm{x}$ & $\mathrm{x}$ \\
\hline Firstborn girl*State FE & $\mathrm{x}$ & $\mathrm{x}$ & $\mathrm{x}$ & $\mathrm{x}$ & $\mathrm{x}$ & $\mathrm{x}$ \\
\hline Firstborn girl*Caste FE & $\mathrm{x}$ & $\mathrm{x}$ & $\mathrm{x}$ & $\mathrm{x}$ & $\mathrm{x}$ & $\mathrm{x}$ \\
\hline Caste*State*YOB FE & & $\mathrm{x}$ & & $\mathrm{x}$ & & $\mathrm{x}$ \\
\hline
\end{tabular}

NOTES: This table reports the coefficients corresponding to specifications (1) and (2) estimated for households where all children have the same mother. Each column is a separate regression. The dependent variable is per capita household saving in financial institutions in columns (1) and (2), plus per capita cash saving in columns (3) and (4), and plus per capita interest earning in the last two columns. Firstborn girl indicates that the firstborn child of the household is female. Expected dowry (in INR 10,000) for a female (male) child is defined as the median net dowry paid (received) by brides (grooms) from the same caste and state as the child and who married during the year of the child's birth or the prior four years. Caste refers to indicators for SC, ST, OBC, and upper castes. YOB refers to the year of birth of the firstborn child. State refers to the state of residence at the time of survey. $\mathbf{X}_{i}$ controls for parents' age, schooling, religion, and month of survey. Standard errors in brackets are clustered by state. ${ }^{* * *} 1 \%, * * 5 \%, * 10 \%$. 
Table A.12: Father's labor supply: Using median dowry to proxy for expected dowry

\begin{tabular}{lccc}
\hline Dependent Variable: & \multicolumn{3}{c}{ Father's days worked in a year } \\
\hline & All & Above poverty line & Below poverty line \\
& $(1)$ & $(2)$ & $(3)$ \\
\hline Firstborn girl * Post* Expected dowry & $5.83^{* * *}$ & $7.01^{* * *}$ & 4.75 \\
& {$[1.75]$} & {$[1.89]$} & {$[4.58]$} \\
Expected dowry * Post & 2.37 & 1.80 & 2.03 \\
& {$[3.23]$} & {$[4.49]$} & {$[3.98]$} \\
Firstborn girl * Post & $-11.12^{* *}$ & $-13.09^{* *}$ & -13.90 \\
& {$[4.62]$} & {$[5.55]$} & {$[9.76]$} \\
\hline $\mathrm{N}$ & 71,282 & 36,703 & 29,395 \\
\hline
\end{tabular}

NOTES: This table reports the coefficients corresponding to specification (4). The sample is restricted to households where all children have the same mother. Each column corresponds to a different regression. The dependent variable is the number of days worked each year. Firstborn girl indicates that the firstborn child of the household is female. Post indicates that the year of labor is later than the first child's year of birth. Expected dowry (in INR 10,000) for a female (male) child is defined as the median net dowry paid (received) by brides (grooms) from the same caste and state as the child and who married during the year of the child's birth or the prior four years. Standard errors in brackets are clustered by state. *** $1 \%, * * 5 \%, * 10 \%$. 
Table A.13: Using gross (instead of net) marriage payments

\begin{tabular}{lcc}
\hline Dependent variable: & $\begin{array}{c}\text { Household per capita saving in 2007 } \\
\text { (financial institutions + cash + interest earned) } \\
(1)\end{array}$ & $\begin{array}{c}(2) \\
\text { FE for \#children }\end{array}$ \\
\hline Firstborn girl * Expected gross payment by bride & $662.60^{*}$ & $656.62^{*}$ \\
& {$[356.92]$} & {$[357.88]$} \\
Firstborn girl * Expected gross payment by groom & 1066.17 & 1094.13 \\
& {$[2129.19]$} & {$[2148.93]$} \\
Firstborn girl & -2572.92 & -2539.77 \\
& {$[3757.24]$} & {$[3787.71]$} \\
\hline $\mathrm{N}$ & & 2,840 \\
\hline
\end{tabular}

NOTES: Instead of net dowry expectation in specification (2), here we use two gross dowry variables: Expected gross (wedding) payment by bride and Expected gross (wedding) payment by groom. Expected gross payment (in INR 10,000) by bride (groom) are defined as the average value of gifts given by brides (grooms) from the same caste and state as the child and who married during the year of the child's birth or the prior four years. Household data is restricted to households where all children have the same mother. Each column is a separate regression. Column (2) also controls for indicators for the number of children. Firstborn girl indicates that the firstborn child of the household is female. Standard errors in brackets are clustered by state. *** $1 \%, * * 5 \%, * 10 \%$. 
Table A.14: Robustness check: Drop one state at a time

\begin{tabular}{|c|c|c|c|c|}
\hline \multirow{2}{*}{$\begin{array}{l}\text { Dependent Variable: } \\
\text { Dropped state: }\end{array}$} & \multicolumn{2}{|c|}{ PC Saving + Cash + Interest } & \multicolumn{2}{|c|}{ Father's days worked } \\
\hline & $\begin{array}{c}\text { Coeff of } \\
F G^{*} \text { Dowry } \\
\text { (1) }\end{array}$ & $\begin{array}{l}\mathrm{N} \\
(2)\end{array}$ & $\begin{array}{c}\text { Coeff of } \\
F G^{*} \text { Post }^{*} \text { Dowry } \\
\text { (3) }\end{array}$ & $\begin{array}{l}\mathrm{N} \\
(4)\end{array}$ \\
\hline KERALA & $\begin{array}{l}617.54^{*} \\
{[304.40]}\end{array}$ & 2,831 & $\begin{array}{c}3.94^{* *} \\
{[1.61]}\end{array}$ & 71,057 \\
\hline KARNATAKA & $\begin{array}{l}615.26^{*} \\
{[322.66]}\end{array}$ & 2,575 & $\begin{array}{l}3.30^{*} \\
{[1.83]}\end{array}$ & 64,608 \\
\hline MAHARASHTRA & $\begin{array}{l}644.16^{*} \\
{[316.86]}\end{array}$ & 2,675 & $\begin{array}{c}3.66^{* *} \\
{[1.69]}\end{array}$ & 67,053 \\
\hline GUJARAT & $\begin{array}{c}514.00 \\
{[322.70]}\end{array}$ & 2,544 & $\begin{array}{l}3.92^{* *} \\
{[1.64]}\end{array}$ & 63,807 \\
\hline MADHYA PRADESH & $\begin{array}{l}642.88^{*} \\
{[331.19]}\end{array}$ & 2,548 & $\begin{array}{l}4.44^{* *} \\
{[1.51]}\end{array}$ & 63,966 \\
\hline RAJASTHAN & $\begin{array}{l}618.36^{*} \\
{[306.96]}\end{array}$ & 2,762 & $\begin{array}{l}3.53^{*} \\
{[1.70]}\end{array}$ & 69,342 \\
\hline HARYANA & $\begin{array}{l}439.11^{*} \\
{[208.92]}\end{array}$ & 2,637 & $\begin{array}{l}2.60 \\
{[1.54]}\end{array}$ & 66,213 \\
\hline PUNJAB & $\begin{array}{c}807.30 * * \\
{[374.34]}\end{array}$ & 2,693 & $\begin{array}{l}2.41 \\
{[2.05]}\end{array}$ & 67,610 \\
\hline HIMACHAL PRADESH & $\begin{array}{l}547.89^{*} \\
{[309.65]}\end{array}$ & 2,808 & $\begin{array}{c}3.68^{* *} \\
{[1.68]}\end{array}$ & 70,488 \\
\hline UTTAR PRADESH & $\begin{array}{c}617.83 \\
{[355.07]}\end{array}$ & 2,450 & $\begin{array}{l}3.38^{*} \\
{[1.91]}\end{array}$ & 61,562 \\
\hline BIHAR & $\begin{array}{l}675.91^{*} \\
{[328.51]}\end{array}$ & 2,774 & $\begin{array}{c}3.88^{* *} \\
{[1.66]}\end{array}$ & 69,638 \\
\hline WEST BENGAL & $\begin{array}{l}602.73^{*} \\
{[311.92]}\end{array}$ & 2,695 & $\begin{array}{c}3.89^{* *} \\
{[1.67]}\end{array}$ & 67,659 \\
\hline JHARKHAND & $\begin{array}{l}625.44^{*} \\
{[305.82]}\end{array}$ & 2,771 & $\begin{array}{l}3.88^{* *} \\
{[1.67]}\end{array}$ & 69,559 \\
\hline CHHATTISGARH & $\begin{array}{l}619.37^{*} \\
{[314.26]}\end{array}$ & 2,702 & $\begin{array}{l}3.35^{*} \\
{[1.78]}\end{array}$ & 67,810 \\
\hline ORISSA & $\begin{array}{l}661.36^{*} \\
{[319.34]}\end{array}$ & 2,711 & $\begin{array}{l}3.95^{* *} \\
{[1.65]}\end{array}$ & 68,011 \\
\hline ANDHRA PRADESH & $\begin{array}{l}673.55^{*} \\
{[329.01]}\end{array}$ & 2,569 & $\begin{array}{l}3.37^{*} \\
{[1.72]}\end{array}$ & 64,440 \\
\hline TAMIL NADU & $\begin{array}{l}636.45^{*} \\
{[316.14]}\end{array}$ & 2,695 & $\begin{array}{l}4.17^{* *} \\
{[1.57]}\end{array}$ & 67,689 \\
\hline
\end{tabular}

NOTES: Standard errors in brackets are clustered by state. *** $1 \%, * * 5 \%, * 10 \%$. 


\section{B Note on Missing Observations}

In total, data on the year of marriage is available and is during 1960-2008 for 40,623 marriages. We exclude marriages where data on both gifts given and received is missing $(1,079)$ leaving us with 39,544 observations. While 18,275 (46 percent) observations have information on both gifts, the remaining 21,269 (54 percent) have one of them missing. In the latter case, when only one of the two is missing, we assume that the missing value equals zero. Note, however, that in 95 percent of the cases where one of the gifts is missing, the missing data is for gifts from the groom's side. This implies that by replacing missing data with zeros we are primarily underestimating gifts from the groom's side, and in turn overestimating net dowry.

Figure B.4 plots the trends in net dowry for our sample and for the sub-sample where both gifts are non-missing. The two lines are largely similar except in recent years for which we do not have a large enough sample size, suggesting that our analysis is not substantively affected by the treatment of missing data. This is not surprising since the bulk of the missing information is for groom's payments that are several orders of magnitude smaller than the bride's payments.

Figure B.4: Trends in Real Marriage Payments (in Rupees), by Year of Marriage

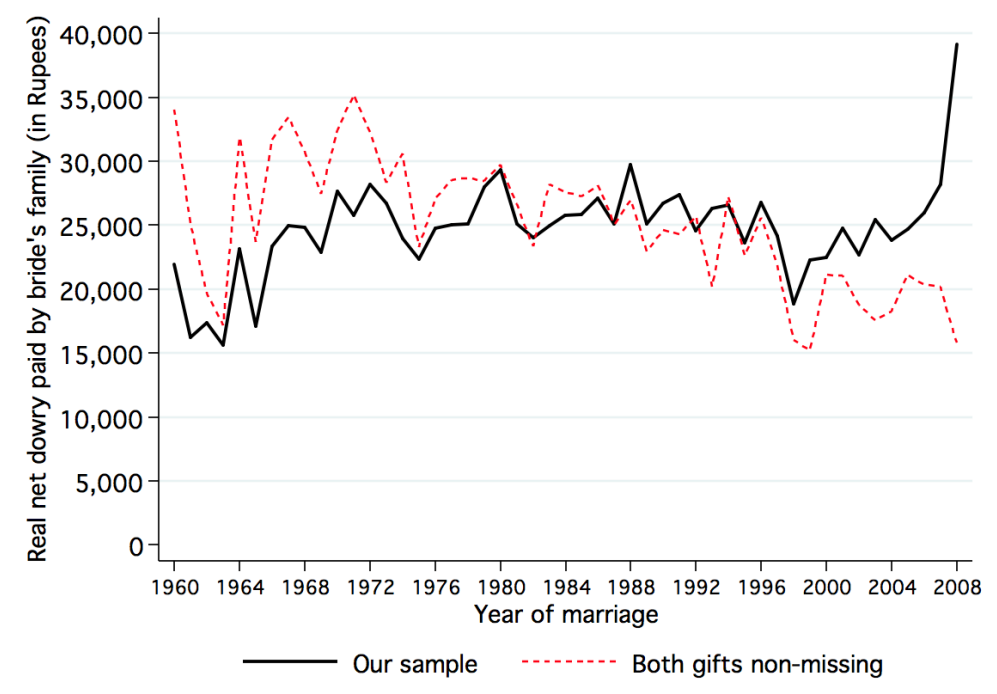

NOTES: This figure plots the raw unweighted average of the net dowry paid by the bride's family by year of marriage. The dashed line only uses observations that have non-missing information on gifts from both bride's and groom's sides. The solid line also includes observations where information on one of the gifts is missing and which we replace with a zero in calculating the net dowry.

Figure B.5 plots the trends for gross payments. In addition to the plots corresponding to Figure B.4 (i.e., our sample and when both gifts are non-missing), a third set of lines 
plots average payments using non-missing data for each gift variable irrespective of whether the other gift variable is missing. As expected, for groom's payments, our sample means are lower (by about INR 5,000) than those calculated using non-missing data. Average bride's payments are also somewhat smaller in our sample and the sample with non-missing bride's payments when compared to the sample where both gifts are non-missing.

Figure B.5: Trends in Real Marriage Payments (in Rupees), by Year of Marriage

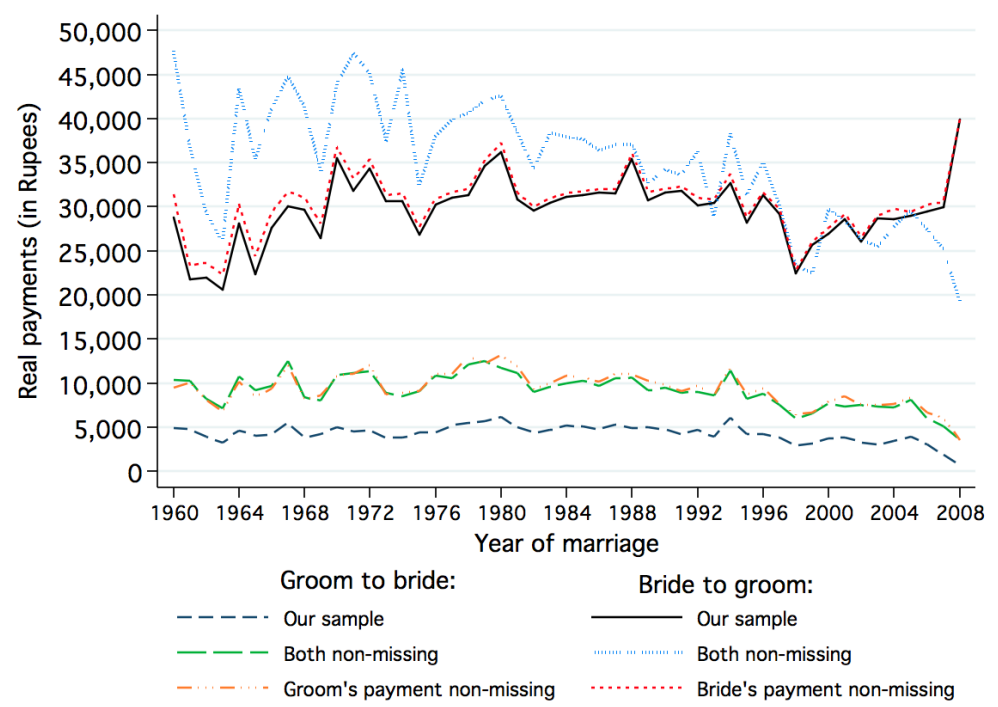

NOTES: This figure plots the raw unweighted average of the net dowry paid by the bride's family by year of marriage. The dashed line only uses observations that have non-missing information on gifts from both bride's and groom's sides. The solid line also includes observations where information on one of the gifts is missing and which we replace with a zero in calculating the net dowry. 